\title{
Türkiye'de Orman, Park ve Fidanlıklarda Görülen Phytophthora Kök Çürüklüğü Hastalıkları ve Korunma Önlemleri
}

\author{
Seçil Akıllı Şimşek ${ }^{1}$, Yakup Zekai Katırcıoğlu², Salih Maden² \\ ${ }^{l}$ Çankırl Karatekin Üniversitesi, Fen Fakültesi, Biyoloji Bölümü, 18100 Çankırl, Türkiye \\ ${ }^{2}$ Ankara Üniversitesi, Ziraat Fakültesi, Bitki Koruma Bölümü, TR-06110 Dısskapı/Ankara, Türkiye
}

M A K A L E B İ L G İ S İ

\section{Araştırma Makalesi}

Geliş 29 Mart 2018

Kabul 11 Nisan 2018

Anahtar Kelimeler:

Phytophthora

Orman

Park

Fidanlık

Türkiye

$\frac{\text { *Sorumlu Yazar: }}{\text { E-mail: secilakilli@gmail.com }}$

Ö Z E T

Phytophthora spp., Oomycetes sınıfinda yer alan, tek ve çok yıllık bitkilerde kök, kök boğazı ve yaprak yanıklığı oluşturarak ani ölümlere yol açan önemli bir hastalık grubudur. Orman ağaçlarında ilk Phytophthora çalışması, Türkiye ormanlarının en yaygın ağacı olan meşelerde yapılmış ve ülkenin birçok bölgesinde, Phytophthora türlerinin bitkilerde kurumalar ve geriye ölüm belirtileri oluşturduğu, bu hastalıklara $P$. cinnamomi, $P$. citricola, $P$. cryptogea, $P$. gonapodyides, $P$. quercina, Phytophthora sp. 1 ve Phytophthora sp. 2 ' in neden olduğu, en yaygın türün ise $P$. quercina olduğu belirlenmiștir. Phytophthora türlerinin yaygın olarak görüldüğü ikinci orman ağacı kestanedir ve ülkemizin hemen hemen her yöresinde Phytophthora kök çürüklüklerine rastlanmıştır. Kestanede dört türün hastalık yaptığı, bunlardan $P$. cambivora 'nın daha çok iç bölgelerde bulunduğu, $P$. cinnamomi' nin ise 1lıman yerlerde sahil bölgelerde bulunduğu, $P$. plurivora ve $P$. cryptogea' nın daha az oranda bulunduğu belirlenmiştir. Bu türlerden $P$. cambivora ve $P$. cryptogea, karaçamlarda da saptanmıștır. Diğer orman ağaçlarından Dişbudaklarda $P$. lacustris, Şimşirlerde $P$. plurivora, $P$. occultans; Atkestanelerinde $P$. citrophthora ve $P$. cactorum; Kokarağaçta $P$. nicotianae tespit edilmiștir. Ülkemizde incelenen birçok orman ve süs bitkisi üreten fidanlıklarda da Phytophthora hastalıkları belirlenmiştir. Değişik fidanlıklarda; $P$. cinnamomi, $P$. cryptogea, $P$. cactorum, $P$. citricola, $P$. megasperma ve $P$. syringae türlerinin hastalik oluşturduğu belirlenmiştir. Bu derlemede bu bulgular ile ilgili detaylı bilgi sunulmuştur.

Turkish Journal of Agriculture - Food Science and Technology, 6(6): 770-782, 2018

\section{Phytophthora Root Rot Diseases Occurring on Forest, Parks, and Nurseries in Turkey and Their Control} Measures

\section{A R T I C L E IN F O}

\section{Research Article}

Received 29 March 2018

Accepted 11 April 2018

Keywords:

Phytophthora

Forest

Garden

Nursery

Turkey

*Corresponding Author:

E-mail: secilakilli@gmail.com

\section{A B S T R A C T}

Phytophthora species, as a member of Oomycetes are important plan diseases occurring on almost all of the annual and perennial plants and rapidly killing the plants by producing root, collar rots and leaf blights. The first Phytophthora study on forest trees in Turkey was made on oak species which is the most widespread tree in the country. Seven Phytophthora species, namely $P$. cinnamomi, $P$. citricola, $P$. cryptogea, $P$. gonapodyides, P. quercina, Phytophthora sp. 1 and Phytophthora sp. 2' were found to cause dieback and death on oaks, $P$. quercina being the most frequently encountered. The second most common tree having Phytophthora infections is sweet chestnut and root rots caused by Phytophthora were determined everywhere chestnut grow in the country. Four species were found on chestnut and the most frequently occurring two species are $P$. cambivora and $P$. cinnamomi occurring in the inner part and in the coastal areas of the country respectively. The third and fourth species, $P$. plurivora and $P$. cryptogea were observed in the decreasing order respectively. From the above mentioned species, P. cambivora and $P$. cryptogea were also reported from black pine at one location in the newly reforested location. From the other forest trees; various Phytophthora species were reported; $P$. lacustris from narrow leaved ash, $P$. plurivora, $P$. occultans from boxwood, $P$. citrophthora and $P$. cactorum from horse chestnut, $P$. nicotianae from Ailanthus sp. Phytophthora diseases were also found in a few nurseries growing forest an ornamental trees. P. cinnamomi, $P$. cryptogea, $P$. cactorum, $P$. citricola, $P$. megasperma and $P$. syringae were found to cause disease on various forest tree saplings. Elaborate information on Phytophthora diseases is being given in the review. 


\section{Giriş}

Phytophthora; NCBI taksonomi web sayfasinda, cellular organizms (hücresel organizmalar), Eukaryota (Gerçek çekirdekliler), Stramenopiles (fungus benzeri organizmalar), Oomycetes (sınıf), Peronosporales (takım) olarak sinıflandırılan; tür, melez, f. sp, var., ırk veya türden farklı (aff.) olarak 272 ve sinıflandırılmayan 567 takson içermektedir (Anonymous, 2018).

Phytophthora türlerinin az sayıda türe özelleşmiş (f. sp.), Irk veya varyeteleri olmasına rağmen bu türler çoğunlukla birden fazla konukçuyu hastalandırmaktadırlar (Hansen ve ark., 2013). Örneğin; P. ramorum Werres et al., P. cinnamomi Rands gibi bazı türlerin çok sayıda konukçuları vardır. Çok yıllık bitkilere saldıran Phytophthora türleri, bazı türler, $P$. ramorum ve $P$. kernoviae Brasier gibi, hariç genellikle bitkilerin toprak altı kısımlarını enfekte etmekte, kök ve kök boğazında çürüklüklere neden olmaktadırlar (Jung ve Blaschke, 1995; Erwin ve Ribeiro, 1996; Brasier ve Jung, 2006; Denman ve ark., 2009; Lilja ve ark., 2006) (Şekil 1a,b).

Kök ve kök boğazı enfeksiyonunun şiddetine bağlı olarak bitkilerde uçtan itibaren geriye doğru kuruma (dieback), ağaç taç kısmında seyrekleşme (Şekil 2a) ve enfeksiyon tüm kök veya kökboğazı çevresini kuşattığı zaman bitkide solgunluk ve kalıcı ölüm oluşmaktadır (Hook, 2011) (Şekil 2b). Yukarıda belirtilen bu etkiler enfeksiyon sonucu oluşan su iletiminin aksaması ile ortaya çıkmaktadır.

Şu anda Dünyada en çok yayılış gösteren $P$. ramorum ve $P$. kernoviae gibi bazı türler ise bitkilerin tüm yeşil aksamını enfekte ederler ve bitkilerde yanıklık (blight) olarak adlandırılan belirtilere yol açarlar (Şekil 3). Bu türler sporlarının daha kolay dağıtılması nedeniyle çok çabuk yayılırlar ve büyük tehlikeler oluştururlar. $P$. ramorum ABD'de, Avrupa'da orman ve parklardaki Meşelerde gövdelerde akıntılı kanserlere neden olup ani ölümlere, Avrupa ve Kuzey Amerika'daki orman, park ve bahçelerde odunsu çalılar, süs bitkilerinde ise yaprak ve dallarda yanıklık, geri ölümlere neden olmaktadır (Grünwald ve ark., 2008).

Phytophthora türleri, Amerika ve Avrupa (Avusturalya) orman ağaçlarında ciddi zararlar oluşturmaktadırlar. Ayrıca Avrupa ve Amerika ormanlarında pek çok Phytophthora türünün önemli zarar oluşturduğu da kayıtlıdır. Örneğin Brasier ve Jung (2003 ve 2006) Avrupa' da Akçaağaç, Kayın, Atkestanesi, Kestane ve Meşe ormanlarında birçok Phytophthora türünün zararlı olduğunu vurgulamışlardır. Diğer yandan Amerika' da sedir, Notholithocarpus densiflorus (Hook. \& Arn.) Manos, Cannon \& S.H.Oh, meşe, yalanc1 servi gibi türlerde de Phytophthora' ların zararlı olduğu bildirilmiştir (Hansen, 2015).

Pek çok Phytophthora türünün orman, park ve süs bitkilerinde yaygın olması nedenleri araştırılmış ve Avrupa'da 732 fidanlık ve 2525 orman fidanı, büyük ağaç, peyzaj bitkileri ve süs bitkileri üretim alanlarında yapılan inceleme sonucunda; 670 adet fidanlığın $(\% 91,5)$ 49'u Phytophthora taksonu ile bulaşık olduğu saptanmıştır. Ele alınan diğer 2525 yetiştirme alanlarının 1667'sinde ise (\%66) 56 Phytophthora taksonunun bulunduğu belirlenmiştir. $\mathrm{Bu}$ türlerden pek çoğunun Avrupa için egzotik türler olduğu da vurgulanmıştır. $\mathrm{Bu}$ bulaşıklılık kaynağının Avrupa orman ekosistemi için büyük risk taşıdığg da bildirilmiş̧tir (Jung ve ark., 2016).

Ülkemiz orman, süs bitkileri ve fidanlıklarında bulunan Phytophthora hastalıkları konusu son zamanlarda ele alınmaya başlanmış olup bu derlemede orman ve süs bitkilerinde ülkemizde saptanan Phytophthora türleri, yayılışları toplanmış ve hastalıklarla savaşta alınması gereken önlemler belirtilmiştir.

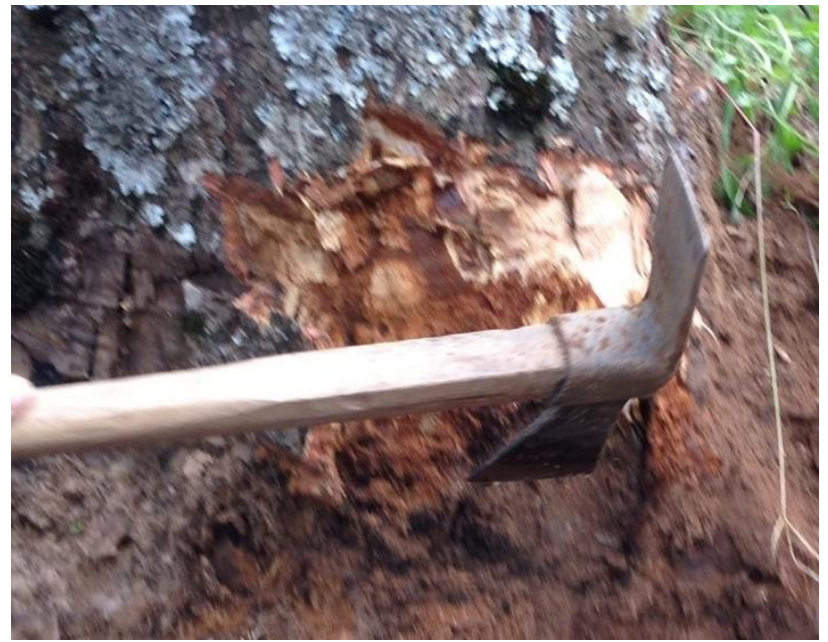

(a)

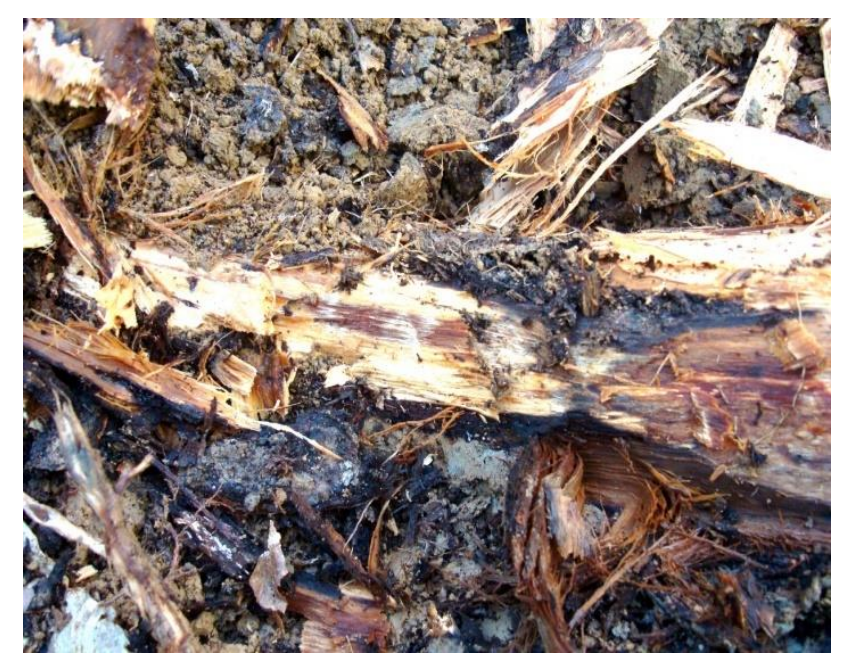

(b)

Şekil 1 Phytophthora cinnamomi'nin oluşturduğu a) kök boğazı çürüklüğü (b) yan köklerdeki kararma belirtileri (Akıllı ve ark., 2012a)

Figurel Symptoms caused by Phytophthora cinnamomi. a) Crown rot, b) Dark necrosis on the secondary roots 


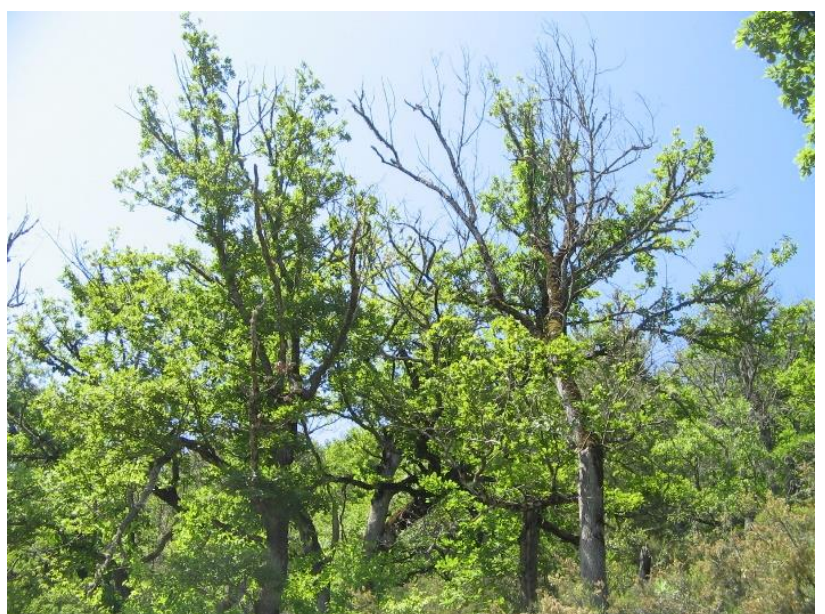

(a)

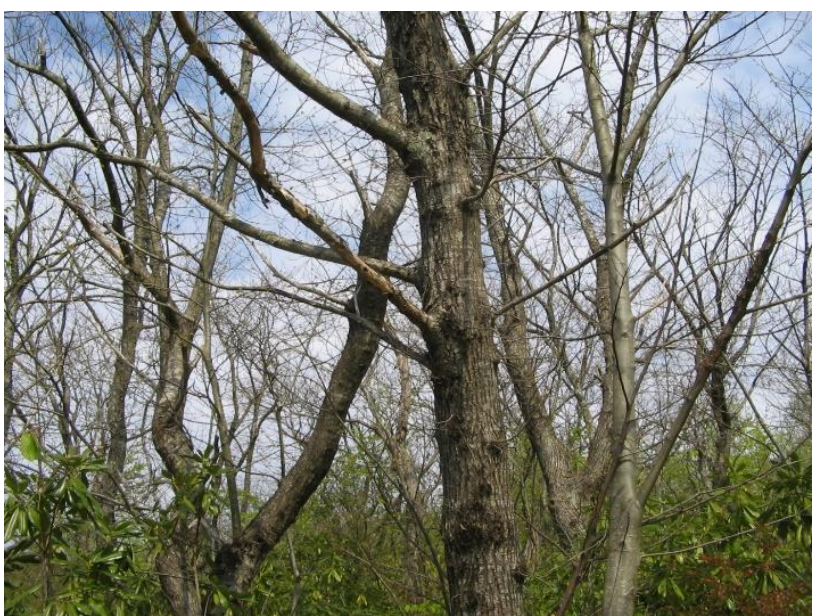

(b)

Şekil 2 Phytophthora plurivora enfeksiyonu ile meşelerde Zonguldak Buldan Deresi mevkiinde oluşan geriye ölüm (a) ve $P$. cinnamomi' nin Zonguldak, Ereğli, Yanık tepe mevkiinde neden olduğu tamamen ölüm (b)

Figure 2 a)Dieback symptoms caused by Phytophthora plurivora on oaks at Buldan Deresi location in Zonguldak, b) Completely killed trees by P. cinnamomi at Yaniktepe location in Zonguldak
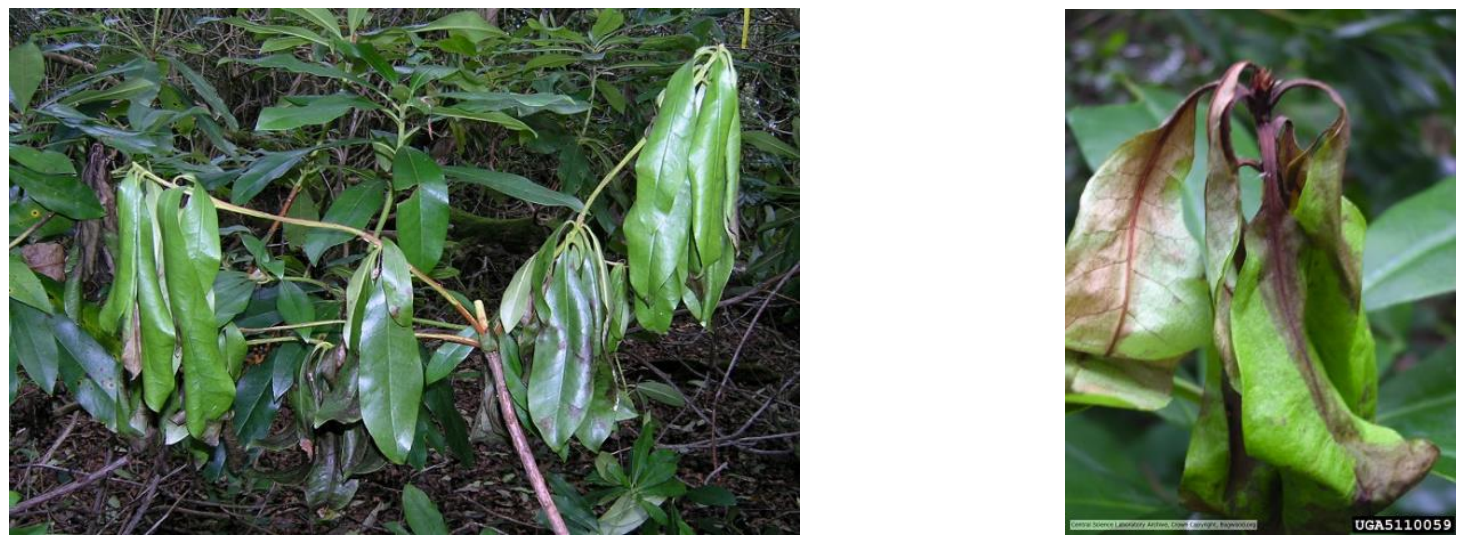

Şekil 3 Phytophthora kernoviae'nın orman güllerinde oluşturduğu yanıklık belirtileri

(http://forestphytophthoras.org/gallery?species $\% 5 \mathrm{~B} \% 5 \mathrm{D}=2344 \&$ disease_symptoms $\% 5 \mathrm{~B} \% 5 \mathrm{D}=6 \&$ disease_symptoms $\%$ $5 \mathrm{~B} \% 5 \mathrm{D}=8 \&$ disease_symptoms $\% 5 \mathrm{~B} \% 5 \mathrm{D}=10 \&$ disease_symptoms $\% 5 \mathrm{~B} \% 5 \mathrm{D}=16 \&$ disease_symptoms $\% 5 \mathrm{~B} \% 5 \mathrm{D}=17$ )

Figure 3 Blight symptoms caused by Phytophthora kernoviae on Rhododendron

\section{Orman Ağaçlarında Görülen Phytophthora Türleri}

Son yıllarda orman, park, süs bitkilerinde ve fidanlıklardaki bitkilerde Phytophthora hastalıkları sık sık rapor edilmektedir ve özellikle fidanlıklardaki bulaşık materyal ile tesis edilen orman ve parklara bu hastalıkların taşındığı belirtilmektedir (Tjosvold ve ark., 2005; Frankel, 2008; Jung ve ark., 2016 ). Avrupa orman ekosisteminde bu hastalıkların önemli olumsuz etkileri olduğu da vurgulanmaktadır.

\section{Meşelerde Saptanan Türler}

Gerek ülkemizde gerekse Avrupa'da en yaygın orman ağaçlarından birisi meşedir. Ülkemizde de meşe 18 türü 4 takson ile en yaygın orman ağacı konumundadır (Aykut ve ark., 2008). Orman Genel Müdürlüğü kayıtlarına göre saf meşe ormanları genel orman alanımızın \%25'ini kaplamaktadır. Ülkemizde 4 milyon ha verimsiz baltalık alanlar ile yaklaşı 300 bin hektar olan kapalı ve verimsiz meşe koru ormanları bulunmaktadır. Bu rakamlara göre de Türkiye'nin toplam orman varlı̆g olan alanın çoğunluğunu kaplamaktadır (Anonim, 2006).

$\mathrm{Bu}$ orman ağacımızda zaman zaman geriye ölüm ve kurumalar görülmüş ve bunun nedenleri araştırılmıştır. $\mathrm{Bu}$ kuruma nedenlerinden birisi de Phytophthora spp.'nin yol açtığ 1 kurumalardır. Meşelerde birçok Phytophthora türünün; Yaprak dökümü, yaprak sararması ve solgunluk, dal ölümleri, kabukta akıntı ve kök çürüklügüne yol açtığı bilinmektedir. Avrupa'da meşelerde çok değişik Phytophthora türlerinin bulunduğu rapor edilmiştir. Bunlar arasinda $P$. cinnamomi, $P$. cambivora (Petri) Buisman, $P$. citricola Sawada, $P$. gonapodyides, $P$. megasperma Drechsler, P. cactorum (Lebert \& Cohn) J. Schröt. ve P.cryptogea Pethybr. \& Laff. vardır. Bu türlere ek olarak 5 yeni tür; $P$. quercina T. Jung and T.I. Burgess, P. europaea Jung et al., P. uliginosa Jung et al., $P$. psychrophila Jung et al. ve $P$. pseudosyringae T. Jung and T.I. Burgess de saptanmıştır. Hala tanımı beklenen taksonlar da bulunmaktadır. Bazı türler geniş coğrafi alanlarda bulunurken, bazıları belirli yerlerden izole edilmişlerdir. İki en yaygın tür $P$. quercina T. Jung and T.I. Burgess olup, bunu $P$. citricola ( $P$. plurivora) izlemiştir (Balcı ve Halmschlager, 2003).

Avrupa'da Phytophthora türlerinin değişik meşe türlerinde çökme ve geriye ölüm hastalıkları oluşturduğu belirlenmiştir. Örneğin; Neves ve Maia (2012) mantar 
meşelerinde (Quercus suber L.) P. cinnamomi, $P$. citrophthora (R.E. Sm. \& E.H. Sm.) Leonian, $P$. cryptogea, $P$. psychrophila, $P$. quercina ve $P$. ramorum' un kanser, kök çürüklüğü ve çökme (decline)'ye neden olduklarını; Corcobado Sánchez (2012) Pırnal meşelerinde (Quercus ilex L.) de P. cinnamomi, $P$. cryptogea, $P$. gonapodyides, $P$. psychrophila, $P$. quercina ve $P$. syringae (Kleb.) Kleb. türlerinin yaprak dökümü, yaprak sararması ve solgunluk, ölü dallar, kabuktan akıntı, kök çürüklüğü ve çökme yaptığını vurgulamıştır. Araştırıcı aynı zamanda fidanlıklarda, $Q$. ilex fidelerinin $P$. cinnamomi, $P$. cryptogea, $P$. drechsleri Tucker, $P$. cambivora ve $P$. gonapodyides tarafindan enfekte edildiğini de belirtmiştir.

Meşelerde en saldırgan tür olarak belirlenen Phytophthora türlerinden biri olan P. cinnamomi daha çok ılıman bölgelerde bulunmakta, yazların çok sıcak ve kışların çok soğuk olduğu yerlerde gelişememektedir (Vettraino ve ark., 2005). İklim değişikliği ile sıcakların az bir artışı ile bu etmenin Avrupa'da daha geniş alanlarda zararlı olacağı vurgulanmaktadır (Brasier, 1996).

Ülkemizde meşelerde Phytophthora hastalıkları ile ilgili ilk çalışma Balcı ve Halmschlager (2003) tarafindan yapılmıştır. Araştırıcılar 1999-2001 yılları arasında Türkiye'nin 51 meşe sahasından toprak örnekleri toplamışlar ve tuzaklama yöntemi ile topraklarda mevcut Phytophthora türlerini belirlemişlerdir. Örneklenen dokuz meşe türünün altısından yedi Phytophthora türü elde edilmiştir. Bunlar; P. cinnamomi, $P$. citricola, $P$. cryptogea, P. gonapodyides, P. quercina, Phytophthora sp. 1 ve Phytophthora sp. 2' dir. Bu türlerden en sik izole edileni $P$. quercina olup daha çok meyilli ve kuraklığa hassas bölgelerde görülmüştür. $\mathrm{Bu}$ tür dört iklim bölgesinde altı meşe türünde saptanmış, bu da meşelerde $P$. quercina'nın yerleşmiş olduğunu göstermektedir. İki genç meşe türü fidanlarında yapılan patojenite çalışmalarında bu tür en düşük saldırganlık göstermiştir. En hassas tür olarak da $Q$. petrea (Matt.) Liebl. bulunmuştur. Meşelerde saptanan diğer ikinci yaygın tür olan $P$. citricola ( $P$. plurivora), $P$. quercina'dan daha saldırgan bulunmuştur. Meşelerde en saldırgan tür ise $P$. cinnamomi olmuştur. Denenen iki meşe türünden $Q$. cerris, $Q$. petrea'ya nazaran Phytophthora spp. ye karş1 daha dayanıklı bulunmuştur.

Tarafimızca yürütülen "Phytophthora türlerinin Karadeniz Bölgesi Orman Ekosisteminin Önemli Odunsu Taksonlarından Meşe (Quercus spp.), Kestane (Castanea sativa) ve Orman gülü (Rhododendron spp.)
Kurumalarındaki Rollerinin Belirlenmesi "adlı TÜBİTAK 1080888 nolu proje kapsamında Karadeniz bölgesi meşe ormanları da Phytophthora yönünden incelenmiş ve sadece Batı Karadeniz bölgesi Zonguldak Orman Bölge Müdürlüğü alanlarından 2 Phytophthora türü; $P$. plurivora ( $P$. citricola) ve $P$. quercina elde edilmiştir (Maden ve ark., 2012).

Akıllı ve ark., (2013b) Zonguldak ile Çaycuma ve Devrek ilçeleri meşe alanlarından alınan toprak örneklerinden siklikla Phytophthora plurivora ve $P$. quercina elde etmişlerdir. Araştırıcılar bu Phytophthora türleri ile birlikte sık sık Pythium türlerini izole etmişler ve bunlardan bir türün ( $P$. anandrum) meşelerde bu bölgede buluna Phytophthora türleri kadar saldırgan olduğunu bulmuşlardır (Şekil 4, Tablo 1). Bu bulgular meşe kurumalarında Phytophthora yanında Pythium türlerinin de payı olabileceği kanısını vermektedir.

Kestanelerde Belirlenen Türler

Kestane ülkemiz ormanlarının önemli bir ağaç türüdür. Orman Genel Müdürlüğü kayıtlarına göre ülkemizde 262,045 ha alanda Avrupa kestanesi (Castanea sativa L.) bulunmaktadır (Anonim, 2014). Ülkemizde kestanelerde Phytophthora varlığına dair ilk kayıt Erdem (1951)'e dayanmaktadır. Erdem (1951); Bazı araştırıcılar tarafından Türkiye'de yaygın kestane kurumlarının olduğunun belirtilmesi üzerine, 1948-1949 yılları arasında Türkiye kestane alanlarında incelemeler yapmıştır. Bu incelemeler sırasında kestane kurumları ile ilgili anket çalışmaları yapılmış ve ayrıca kestane hastalık belirtileri de incelemiştir. Yapılan anket çalışmalarında kestane kurumalarının bazı yörelerde çok öncelerden itibaren var olduğu bildirilmiştir. Örneğin Hopa'da yöre halkının ifadesine göre kestane kurumaları ilk defa takriben 40 yıl önce, Sürmene'de 22-23 yıl, Akçakoca'da 10-12 yıl, Bursa-Fidekızık'da 20-25 yıl önce görüldüğü bildirilmiştir. Araştırıcı yaptığı gözlemlerde kestanelerde genellikle ağaçların uçtan itibaren kuruduğunu, bazen ağaçların aniden yapraklarının sarkarak solduğunu ve ağaçların kök boğazları açıldığında Phytophthora belirtileri için çok tipik olan alev şeklinde nekrozların oluştuğu ve bu kısımlarda koyu renkli akıntılar olduğu ve bu akıntıların olduğu yerlerde toprağın bile siyahlaştığı, gövde nekrozlarının bazı yerlerde topraktan $85 \mathrm{~cm}$ yukarıya kadar ilerlediğini belirtmiştir. Araştırıcı bu tipik belirtilerin Karadeniz ve Marmara bölgelerinin birçok yerinde bulunduğunu fakat hastalığın Ege bölgesindeki Ödemiş, Bozdağ ve Tire yörelerinde bulunmadığını ifade etmiştir.

Tablo 1 Bir Pythium anandrum, 2 Phytophthora quercina ve 4 P. plurivora izolatının sapsız meşe (Quercus petrea) fidanlarında inokülasyondan 60 gün sonra oluşturduğu ortalama nekroz boyları ${ }^{1}$

Table 1 Average necrosis lengths caused by one Pythium anandrum, 2 Phytophthora quercina, and 4 P. plurivora isolates on sessile oak 60 days after inoculation

\begin{tabular}{l|c}
\hline \multicolumn{1}{c|}{ Türler ve izolat numaraları } & Nekroz boyları $(\mathrm{cm})$ \\
\hline P. quercina (M-15) & $5.0 \pm 0.00^{\mathrm{a} 2}$ \\
$P$. quercina (M-13) & $5.7 \pm 2,15^{\mathrm{a}}$ \\
P. plurivora (M-19) & $10.5 \pm 3.98^{\mathrm{a}}$ \\
P. plurivora (M-8) & $11.8 \pm 3.05^{\mathrm{a}}$ \\
Py. anandrum (M-12) & $18.7 \pm 14.50^{\mathrm{b}}$ \\
P. plurivora (M-4) & $19.3 \pm 7.19^{\mathrm{b}}$ \\
P. plurivora (M-7) & $40.2 \pm 14.03^{\mathrm{c}}$ \\
\hline
\end{tabular}

${ }^{1}$ Değerler 10 fidanın ortalamasıdır, ${ }^{2}$ Aynı harfi alan ortalamalar istatistiki olarak farklı değildir $(\mathrm{P} \leq 0.05)$ 


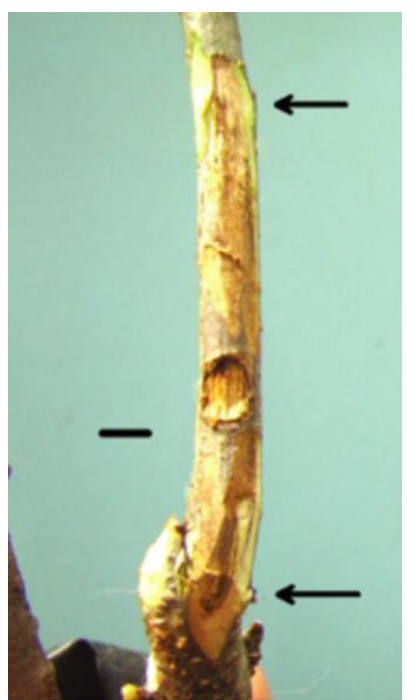

(a)

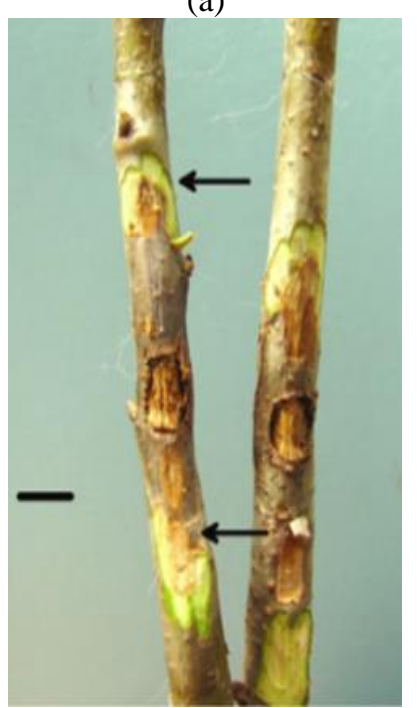

(e)

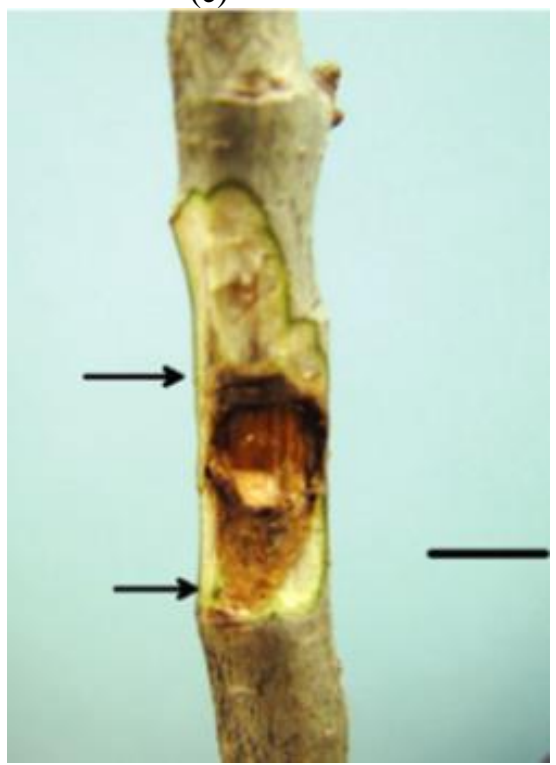

(i)

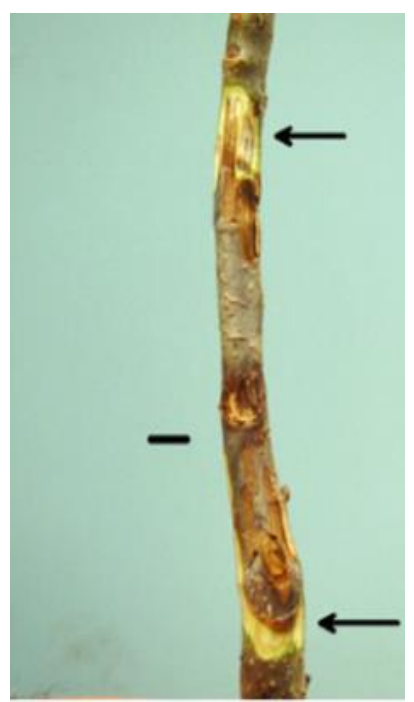

(b)

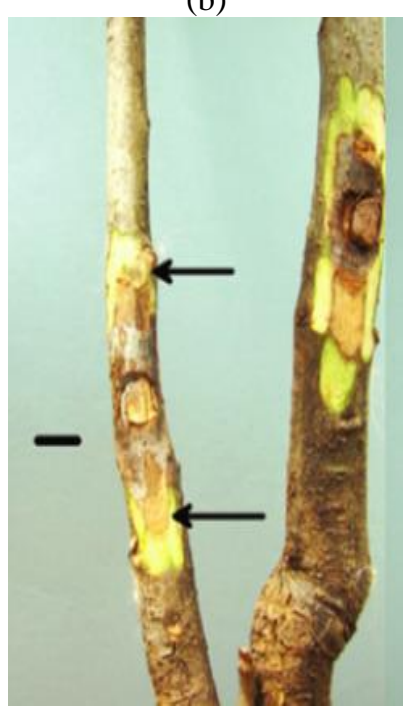

(f)

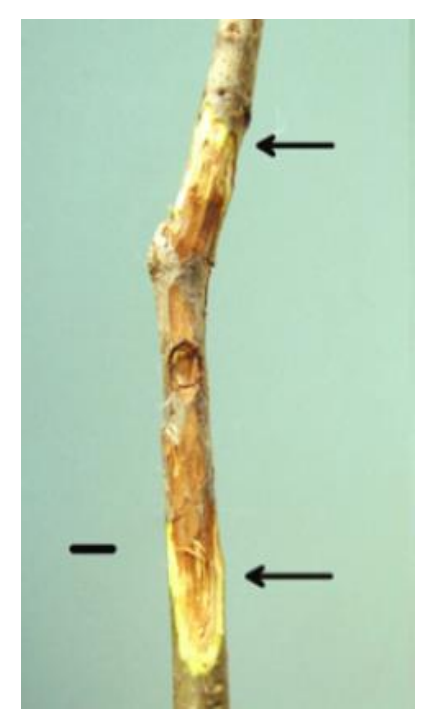

(c)

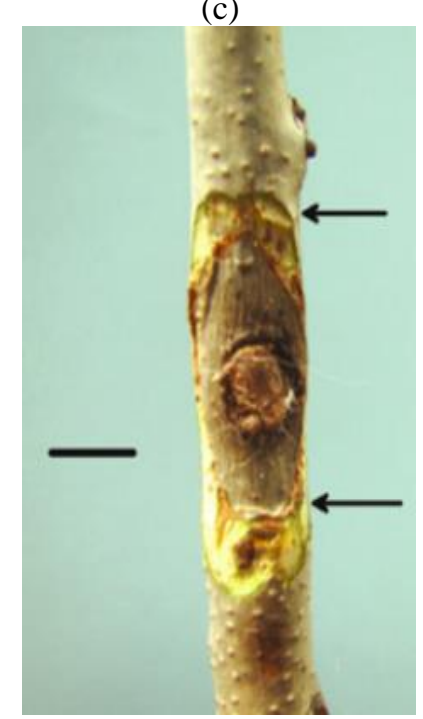

$(\mathrm{g})$

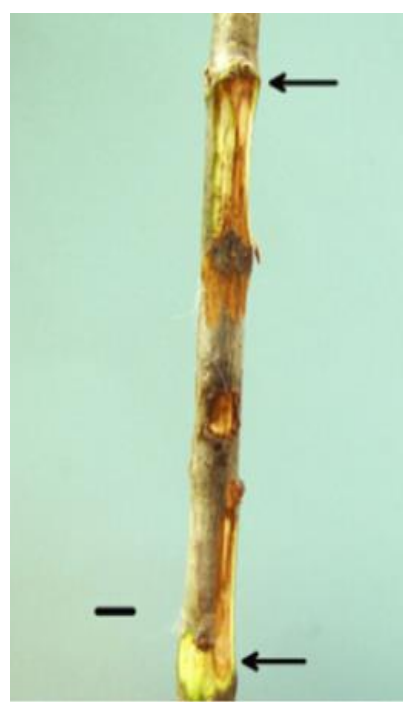

(d)

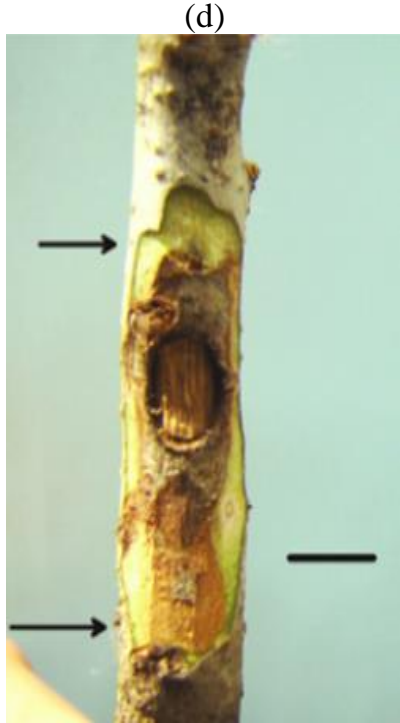

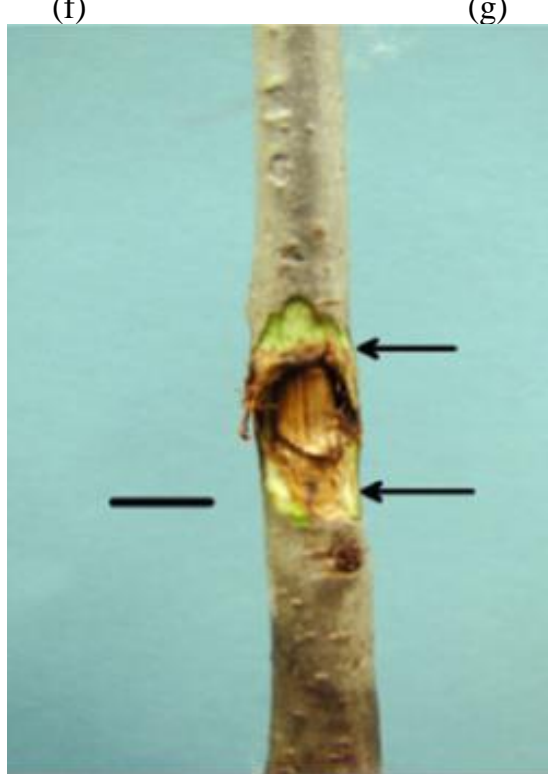

(j) (h)

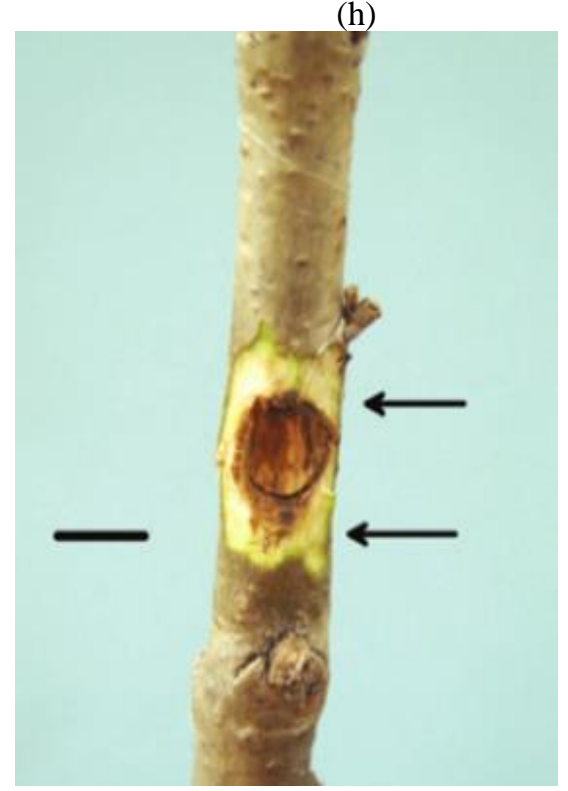

(k)

Şekil 4 Pythium anandrum ve 2 Phytophthora türünün 3 yaşındaki sapsız meşe (Quercus petrea) fidanlarında inokülasyondan 60 gün sonra oluşturdukları nekrozlar. a,b) Py. anandrum; c,d) Phytophthora plurivora (M-7); e,f) P. plurivora (M-4); g, h) P. plurivora (M-8); i,j) P. quercina (M-13); k) Kontrol. Çubuklar 0.5 cm'yi, oklar nekrozların sınırlarını göstermektedir Figure 4 Necrosis caused by Pythium anandrum and 2 Phytophthora species on Sessile oak (Quercus petrea) 60 days after inoculation. a,b) P. anandrum; $c, d)$ Phytophthora plurivora (M-7); e,f) P. plurivora; $(M-4) ;$ g,h) $P$. plurivora $(M-8) ; i, j) P$. quercina (M-13); k) Control. Bars show $0.5 \mathrm{~cm}$, arrows Show the boundaries of the necrosis 
Tablo 2 Karadeniz Bölgesinde kestanelerden elde edilen Phytophthora türleri ve bulundukları yerler* Table 2 Phytophthora species obtained from Black Sea region and their locations of occurrences

\begin{tabular}{|c|c|c|c|}
\hline Phytophthora türleri & Orman Bölge Müdürlüğü & Lokasyon & Koordinatlar \\
\hline P. cambivora & Sinop & $\begin{array}{l}\text { Türkeli } \\
\text { Ayancık }\end{array}$ & $\begin{array}{l}36605511 \mathrm{D}, 4643891 \mathrm{~K} \\
36656042 \mathrm{D}, 4640261 \mathrm{~K}\end{array}$ \\
\hline \multirow{5}{*}{ P. cinnamomi } & Bolu & Akçakoca & $\begin{array}{l}36347471 \mathrm{D}, 4542146 \mathrm{~K} \\
36352465 \mathrm{D}, 4542065 \mathrm{~K} \text { İki fidanlık }\end{array}$ \\
\hline & \multirow{2}{*}{ Giresun } & $\begin{array}{l}\text { Ordu-Ulubey } \\
\text { Ordu-Merkez }\end{array}$ & $\begin{array}{l}37390273 \mathrm{D}, 4527485 \mathrm{~K} \\
\text { Bir fidanlık }\end{array}$ \\
\hline & & $\begin{array}{l}\text { Keşap } \\
\text { Espiye }\end{array}$ & $\begin{array}{l}37468822 \mathrm{D}, 4533496 \mathrm{~K} \\
37469863 \mathrm{D}, 4533386 \mathrm{~K}\end{array}$ \\
\hline & Trabzon & $\begin{array}{l}\text { Sürmene } \\
\text { Rize-Fındıklı } \\
\text { Rize-Fındıklı }\end{array}$ & $\begin{array}{l}37591489 \mathrm{D}, 4527168 \mathrm{~K} \\
37689122 \mathrm{D}, 4570924 \mathrm{~K} \\
37689120 \mathrm{D}, 4570940 \mathrm{~K}\end{array}$ \\
\hline & Zonguldak & $\begin{array}{l}\text { Ereğli-Yanıktepe } \\
\text { Ereğli }\end{array}$ & $\begin{array}{l}36382344 \mathrm{D}, 4576718 \mathrm{~K} \\
\text { Bir fidanlık }\end{array}$ \\
\hline P. plurivora & $\begin{array}{l}\text { Amasya } \\
\text { Sinop }\end{array}$ & $\begin{array}{l}\text { Samsun-Salıpazarı } \\
\text { Erfelek } \\
\text { Türkeli }\end{array}$ & $\begin{array}{l}37314089 \mathrm{D}, 4541904 \mathrm{~K} \\
36659299 \mathrm{D}, 4637830 \mathrm{~K} \\
36607940 \mathrm{D}, 4643040 \mathrm{~K}\end{array}$ \\
\hline
\end{tabular}

*Ak1llı ve ark., 2012a

Tablo 3 Marmara ve Ege Bölgelerindeki illerde kestanelerde belirlenen Phytophthora türleri ve bulunuş oranlar1* Table 3 Phytophthora species determined in Marmara and Aegean regions and their percentages

\begin{tabular}{|c|c|c|c|c|}
\hline Bölgeler & $\begin{array}{l}\text { Orman Bölge } \\
\text { Müdürlükleri }\end{array}$ & $\begin{array}{c}\text { Phytophthora } \\
\text { Türleri }\end{array}$ & $\begin{array}{l}\text { İncelenen ağaç } \\
\text { sayısı }\end{array}$ & $\begin{array}{c}\text { Phytophthora spp. bulunan } \\
\text { örnek say1s1 }(\%)\end{array}$ \\
\hline \multirow{4}{*}{ Marmara } & Adapazarı & P. cambivora & 12 & $3(25 \%)$ \\
\hline & Balıkesir & P. cambivora & 14 & $5(35 \%)$ \\
\hline & Bursa & P. cambivora & 8 & $3(37 \%)$ \\
\hline & İstanbul & P. cinnamomi & 15 & $8(53 \%)$ \\
\hline \multirow{5}{*}{ Ege /Aegean } & & P. cambivora & 32 & $5(15 \%)$ \\
\hline & İzmir & $P$. plurivora & 32 & $4(12 \%)$ \\
\hline & & P. cryptogea & 32 & $1(3 \%)$ \\
\hline & Kütahya & P. cambivora & 9 & $4(44 \%)$ \\
\hline & Muğla & P. plurivora & 20 & $1(5 \%)$ \\
\hline
\end{tabular}

*Ak1llı ve ark., 2018
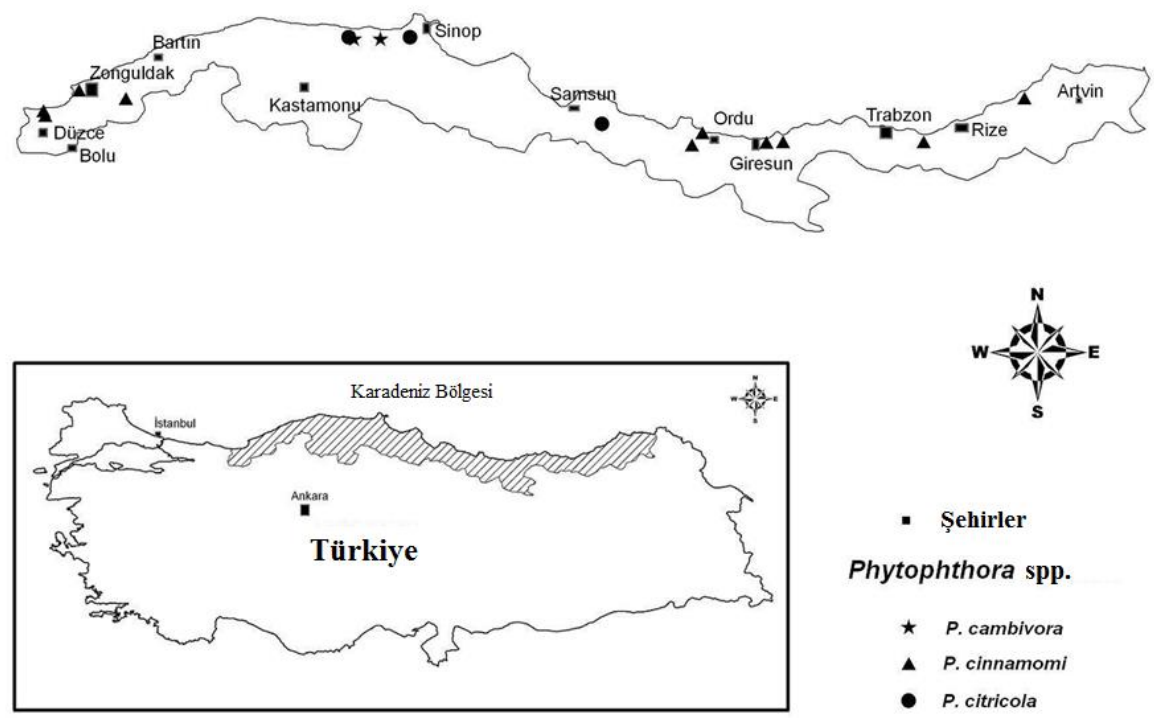

- Şehirler

Phytophthora spp.

$\star$ P. cambivora

A P. cinnamomi

- P. citricola

300

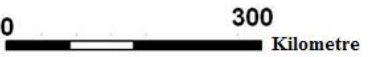

Şekil 5 Karadeniz Bölgesinde kestanelerde saptanan Phytophthora türlerinin dağılımı (Akıllı ve ark., 2012a) Figure 5 Distribution of Phytophthora species determined in Black Sea region of Turkey (Akull et al., 2012a) 
Erdem (1951) hastalıkl1 bitkilerden etmenin izolasyonu ve teşhisi ile ilgili laboratuvar çalışmaları yürütmüş, birkaç defa etmenin miselyal gelişmesine benzer kültürler elde etmesine rağmen hastalık etmeninin tanısında kullanılan sporangium ve zoospor gibi morfolojik özellikleri elde edememiştir. Fakat hastalık belirtilerinin tanımından, kestanede Phytophthora kök çürüklüğünün çok eski yıllardan bu yana ülkemizde bulunduğu anlaşılmaktadır.

Daha sonra Akdoğan (1970), Bursa ili Cumalıkızık köyünde, mürekkep hastalığı ile ilgili yürüttükleri mücadele çalışmaları sırasında, kestanelerde $P$. cambivora 'nın neden olduğu mürekkep hastalığının rivayete göre 1925' den 1968' e kadar Bursa merkezinde 19715 ağacı kuruttuğunu belirtmiştir. Bu kayıtta yer

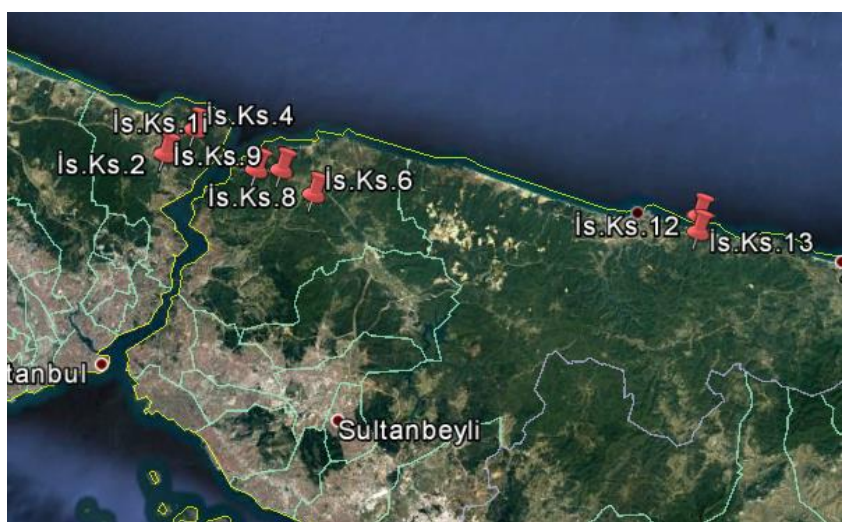

(a)

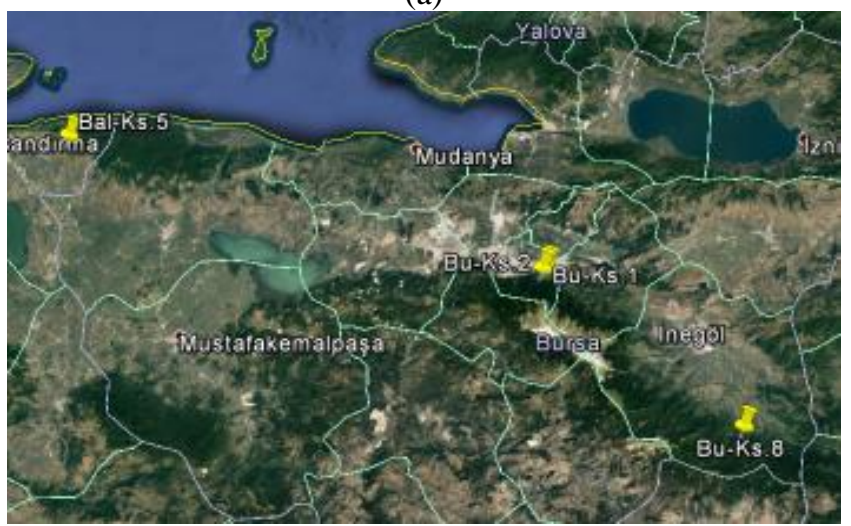

(c)

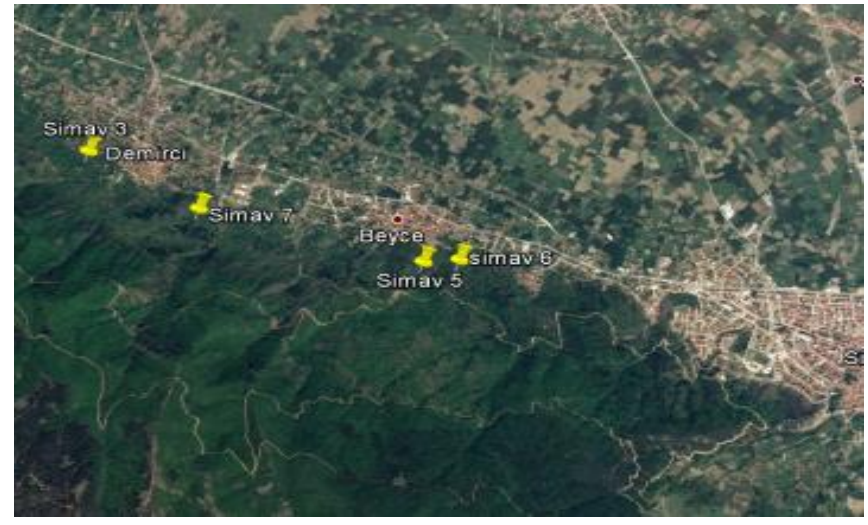

(e) almasına rağmen $P$. cambivora ile ilgili tanısal bir çalışma yapılmamış sadece belirtilere ve kaynaklara dayalı bir hastalık teşhisi ifade edilmiştir. Bu kaynağa dayalı olarak da Biçici ve Çınar (1990) Türkiye' de 20,000 kestane ağacının $P$. cambivora tarafindan öldürüldüğünü rapor etmişlerdir. $\mathrm{Bu}$ etmenin morfolojik özelliklerine dayalı tanısı hakkında bilimsel bir çalışma mevcut değildir. Ayrıca, kestane'de $P$. cambivora' nın neden olduğu Mürekkep hastalığının, Doğu Karadeniz bölgesinde Hopa, Borçka, Sürmene; Batı Karadeniz bölgesinde Zonguldak Akçakoca, İstanbul-Belgrat ormanında, Bursa ve İnegöl civarında mevcut olduğu bir ders kitabında yer almıştır. Ancak bu kaynakta bulguların kime ait olduğu zikredilmemiştir (Çanakçıoğlu ve Eliçin, 1998).

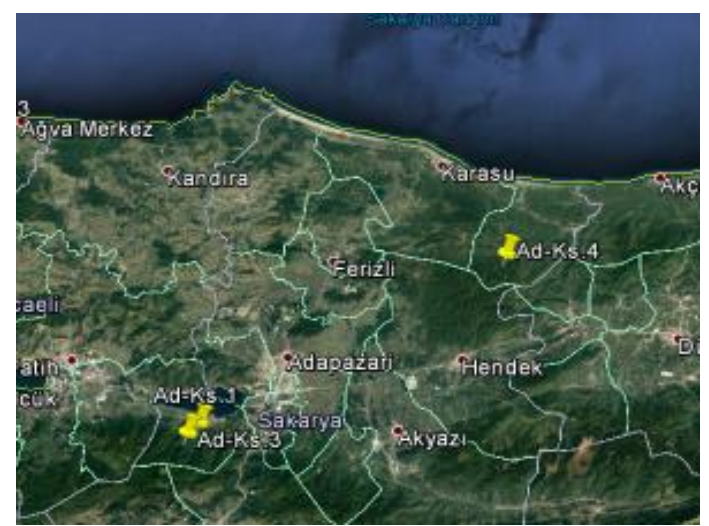

(b)

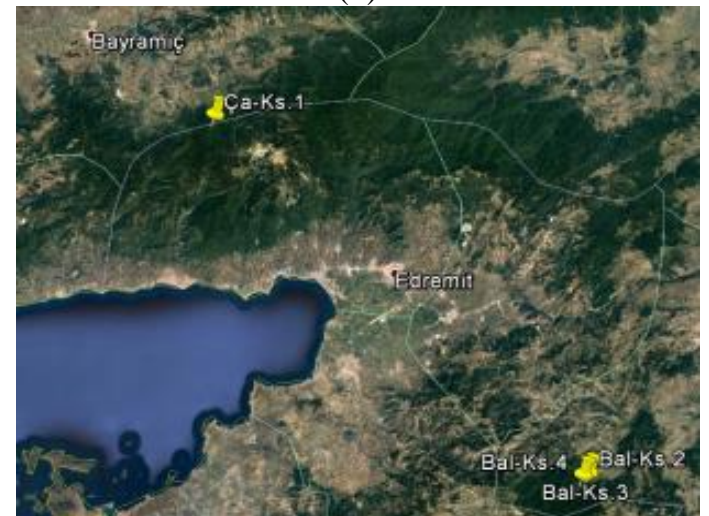

(d)

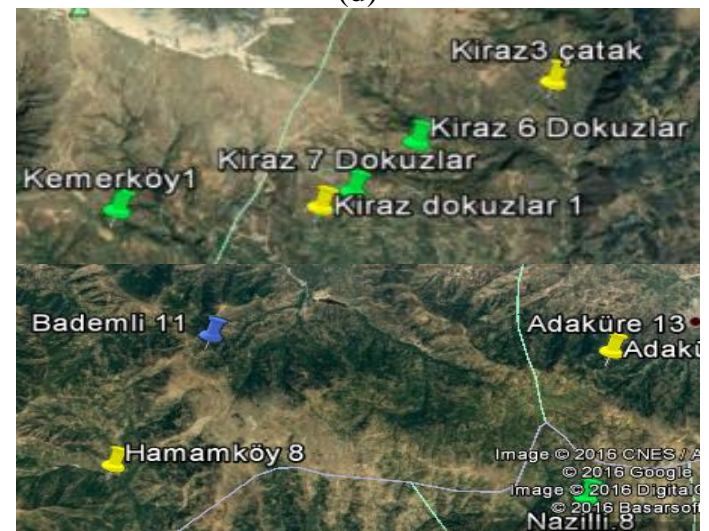

(f)

Şekil 6 Phytophthora türlerinin Marmara ve Ege bölgelerindeki dağılımı. a) İstanbul, b) Adapazarı, c) Bursa, d) Balıkesir, e) Kütahya, f) İzmir ve Muğla orman bölge müdürlükleri alanları. Kırmızı işaretler $P$. cinnamomi, sarılar $P$. cambivora, yeşil $P$. plurivora ve mavi $P$. cryptogea dağılımını göstermektedir

Figure 6 Distribution of Phytophthora species in Marmara and Aegean regions. a) Istanbul, b) Adapazarl, c) Bursa, d) Balıkesir, e) Kütahya, f) İzir ve Muğla regional forestry directorates 


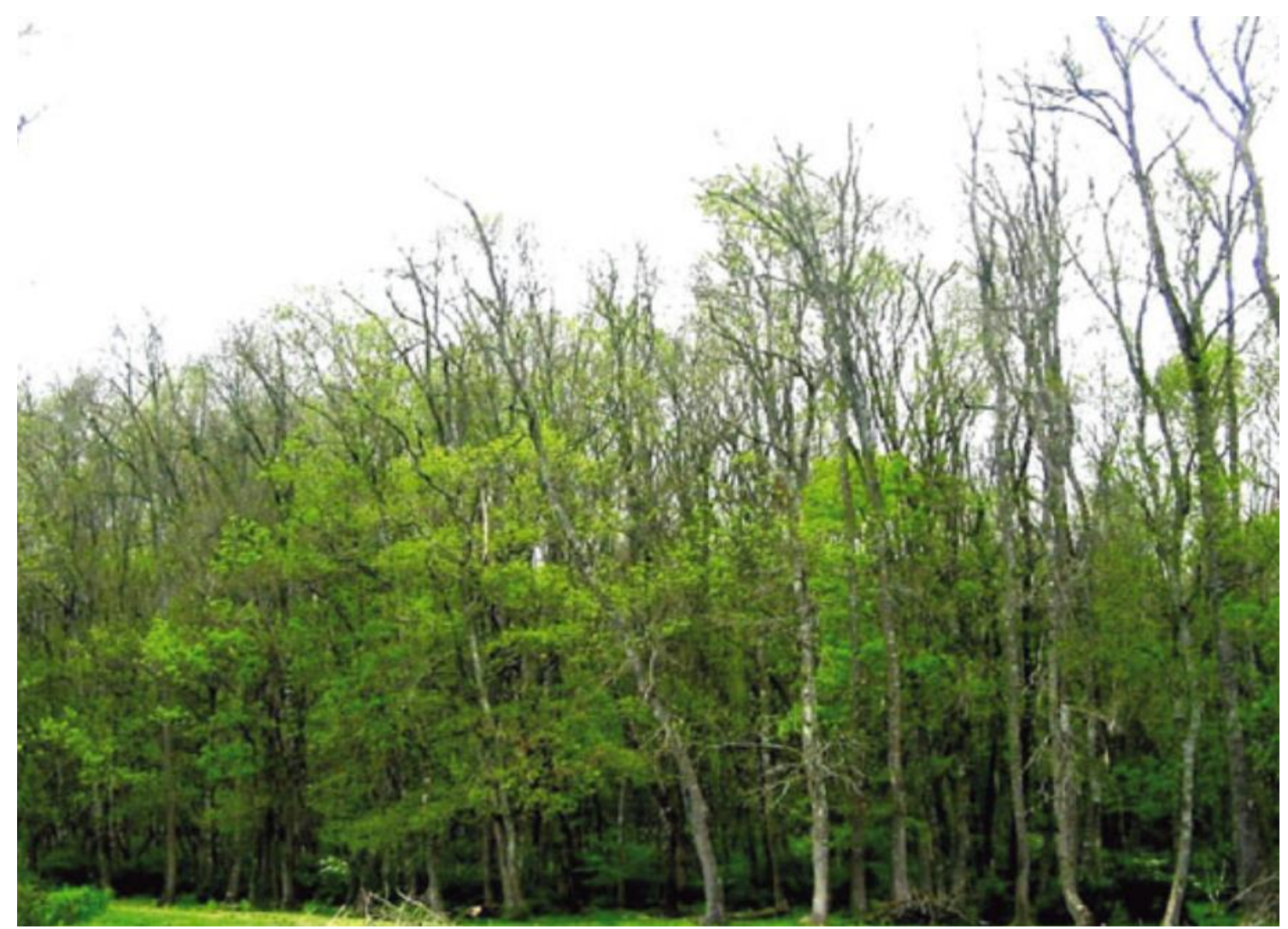

(a)

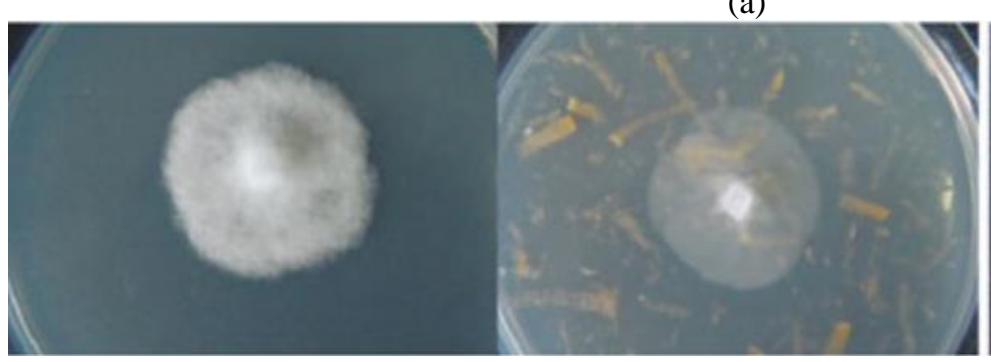

(b)

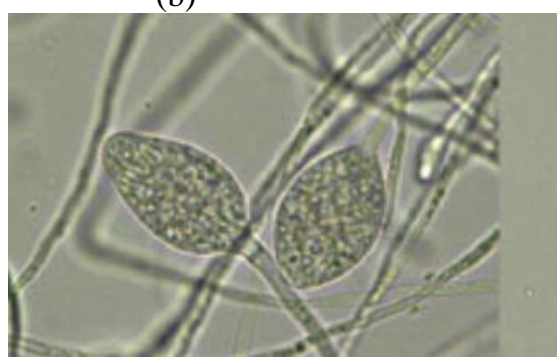

(e)

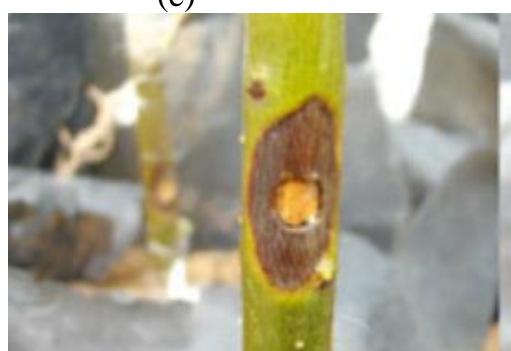

(h) (c)

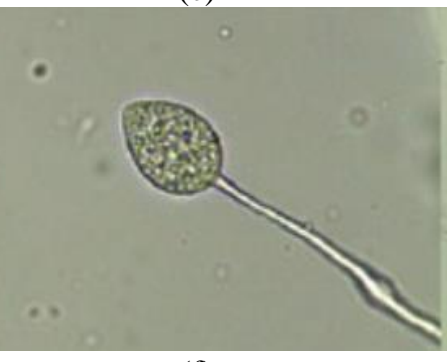

(f)
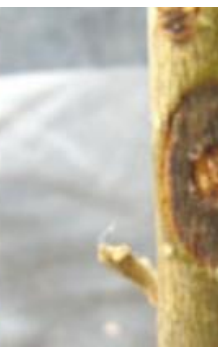

(i)

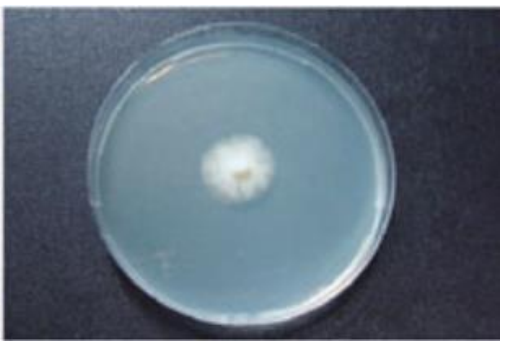

(d)

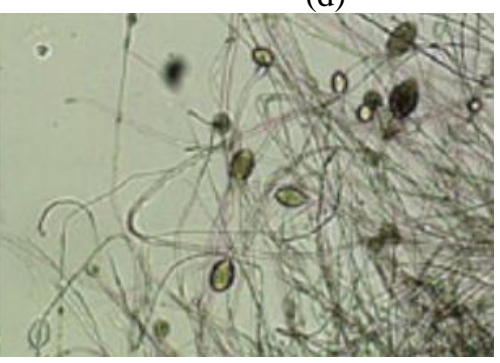

(g)

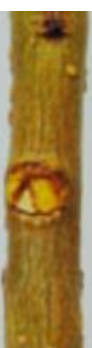

(j)

Şekil 7 a) Geriye ölüm belirtileri gösteren Fraxinus angustifolia subsp. oxycarpa korusu; b,d) Phytophthora lacustris'in sırasıyla CMA, GCA ve PDA ortamlarında, karanlıkta, 22 C'de 7 günlük gelişimi; e,g) GCA ortamında geliştirilen ve toprak ekstraktında oluşan sporangium'ları; h,i) Üç yaşındaki dişbudak fidanlarında oluşan nekrozlar; j) Yara üzerinde kallus oluşumu gösteren fidan

Figure 7 a) Fraxinus angustifolia subsp. oxycarpa stand b, d) Growth of Phytophthora lacustris on CMA, GCA and $P D A$ respectively, in dark, at $22^{\circ} \mathrm{C}$ for 7 days; e-g) Sporangia formed in soil extract grown on GCA; $\left.h, i\right)$ Necrosis formed on three years old saplings; $j$ ) Sapling showing callus formation around the wound 
Türkiye' de kestanelerde morfolojik ve moleküler özelliklere dayalı ilk Phytophthora kaydı Çeliker ve Onoğur (2009) tarafindan yapılmıştır. Araştırıcılar Marmara ve Ege bölgelerinde mürekkep hastalığ 1 belirtileri gösteren; Balıkesir İvrindi'den 3, İzmir Beydağ'dan 1, Kütahya Simav'dan 2 ve Manisa Salihli'den 2 olmak üzere 8 yöreden 11 toprak örneği almışlardır. Araştırıcılar bu toprak örneklerinden Azelae yaprakları kullanarak tuzaklama yöntemi ile Phytophthora türlerini belirlemeye çalışmışlar ve tipik olarak Phytophthora sp.' ye benzeyen 4 izolat elde etmişlerdir. Araştırıcılar bu elde edilen izolatların sadece birinde "K-2" Phytophthora morfolojik özellikleri saptamış ve tanı için bu izolat Almanya'da Sabine Werres' e ve Belçika'da Kris van Poucke'ye gönderilmiş, ilk araştırıcı (Sabine Werres) bu izolatı morfolojik özelliklerine göre $P$. cactorum olarak, ikinci araştırıcı ise moleküler özelliklerine göre $P$. cactorum $\times P$. hedraiandra olarak teşhis etmişlerdir. Araştırıcılar bu izolatın kestane fidelerinde yaptıkları kabuk inokülasyonları sonucunda inokülasyondan 3 ay sonra ortalama 3,9 cm uzunluğunda nekrozlar oluşturduğunu bulmuşlardır.

Ülkemizde kestanelerde kapsamlı Phytophthora kök çürüklüğü çalışmaları ilkin Karadeniz Bölgesinde başlatılmıştır. Akıllı ve ark. (2012a) bu bölgede yürüttükleri çalışmada; 76 yöreden kestane toprak örnekleri toplamışlar ve tuzaklama yöntemi ile kestanelerden 3 Phytophthora türü; $P$. cambivora, $P$. cinnamomi ve $P$. plurivora ( $P$. citricola) izole etmişlerdir. $\mathrm{Bu}$ türlerin tanısı hem etmenlerin morfolojik ve fizyolojik özellikleri, hem de moleküler yöntemlerle etmenlerin ITS bölgesi gen sırasının GenBankası'nda mevcut türlerle karşılaştırılması ile gerçekleştirilmiştir. $\mathrm{Bu}$ türlerden $P$. cambivora Sinop Orman Bölge Müdürlüğü alanında 2 yöreden; $P$. plurivora Sinop ve Amasya Orman Bölge Müdürlükleri alanlarında (Samsun) 3 yöreden, $P$. cinnamomi ise Bolu, Zonguldak, Giresun, Trabzon Orman Bölge Müdürlükleri alanlarından 7 yöreden elde edilmiştir. Elde edilen Phytophthora türlerinin patojenlikleri 2-3 yaşlarında kestane (Castanea sativa) fidanlarında gövde inokülasyon tekniği kullanılarak araştırılmış ve $P$. cinnamomi ile $P$. cambivora en saldırgan türler olduğu, $P$. plurivora'nın bu konukçuda fazla saldırgan olmadığı saptanmıştır. Araştırıcılar bu çalışmalarında Phytophthora türlerinin bulundukları alanların GPS koordinatlarını da sunmuşlardır (Şekil 5, Tablo 2).

Akıllı ve ark. (2012b) ve Katırcığlu ve ark. (2017) Marmara ve Ege bölgelerinde kestanelerde Phytophthora kök çürüklüklerini araştırmışlardır. Araştırıcılar; Marmara Bölgesinden 49, Ege Bölgesinden 61 olmak üzere toplam 110 toprak örneğinde tuzaklama yöntemi ile Phytophthora türlerini belirlemişlerdir. $\mathrm{Bu}$ bölgelerde Phytophthora kök çürüklükleri üniform bir dağılma göstermemiştir. Örneğin $P$. cinnamomi, sadece İstanbul çevresinde bulunurken (Şekil 6) P. cambivora Marmara ve Ege bölgelerinde daha yaygın olarak bulunmuştur (Şekil 6). Araştırıcılar bu bölgelerin her tarafında yer yer Phytophthora kök çürüklüğü belirtileri bulunduğunu, ancak alınan örneklerin hepsinde bu etmeni bulamadıklarını, bunu da toprak örneklerinin alındığı dönemlerde devam eden kuraklığa bağladıklarını vurgulamışlardır.

Örneklerden en yüksek oranda Phytophthora spp. tespiti \%53 ile İstanbul bölgesi olmuş, bunu \%47 ile Kütahya ve \%37 ile Bursa bölgeleri izlemiştir. Ege bölgesinde Phytophthora spp. tespit oranları Kütahya bölgesi hariç düşük olmuştur (Tablo 3).

\section{Diğer Orman Ağaçlarında Saptanan Türler}

\section{Dişbudak}

Ülkemizde daha çok sulak alanlarda sınırlı olarak bulunan dişbudak ağaçlarında yer yer geriye ölüm belirtileri Sinop yakınlarında 490 ha $11 \mathrm{k}$ bir alanda görülmüştür. Bu geriye ölüm belirtileri gösteren ağaçlarda dişbudaklarda kanser ve geriye ölüme yol açan Chalara fraxinea T. Kowalski (teleomorph Hymenoscyphus pseudoalbidus) hastalığ hasta bitkilerin köklerinde çürümelere rastlanmıştır. Bu tip ağaç köklerinden alınan toprak örnekleri Phytophthora bakımından incelenmiş ve 10 örnekten 4'ünde Phytophthora sp. elde edilmiş ve bu tür daha sonra $P$. lacustris Brasier, Cacciola, Nechwatal, T. Jung \& Bakonyi olarak tanılanmıştır (Akıllı ve ark., 2013a) (Şekil 7).
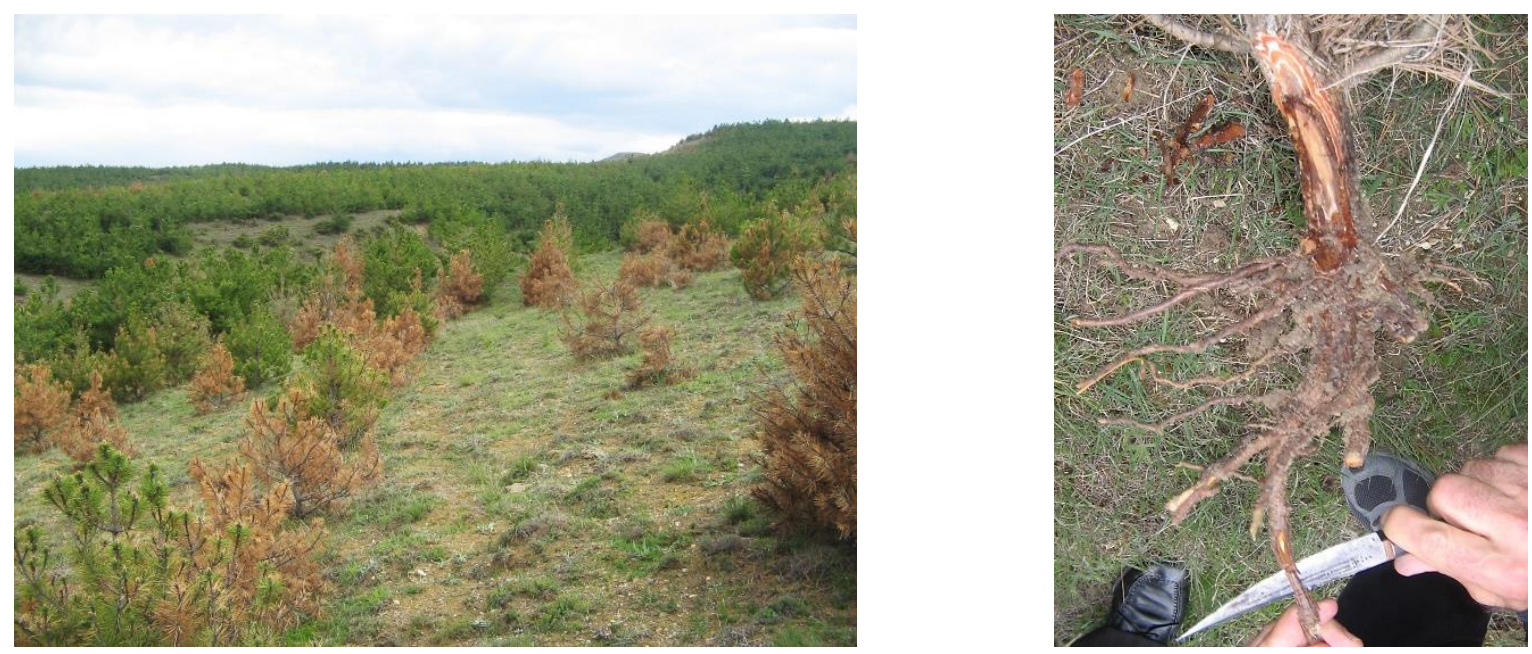

Şekil 8 Kastamonu, Taşköprü Karapürçek karaçam ağaçlama alanında görülen a) Genç ağaçlardaki kurumalar, b) Kurumakta olan ağaçların köklerinde oluşan çürüklük

Figure 8 Symptoms observed in a reforested area with black pine near Taşköprü, Kastamonu. a) Dead young trees b) Necrosis formed on the roots of newly killed young tree 

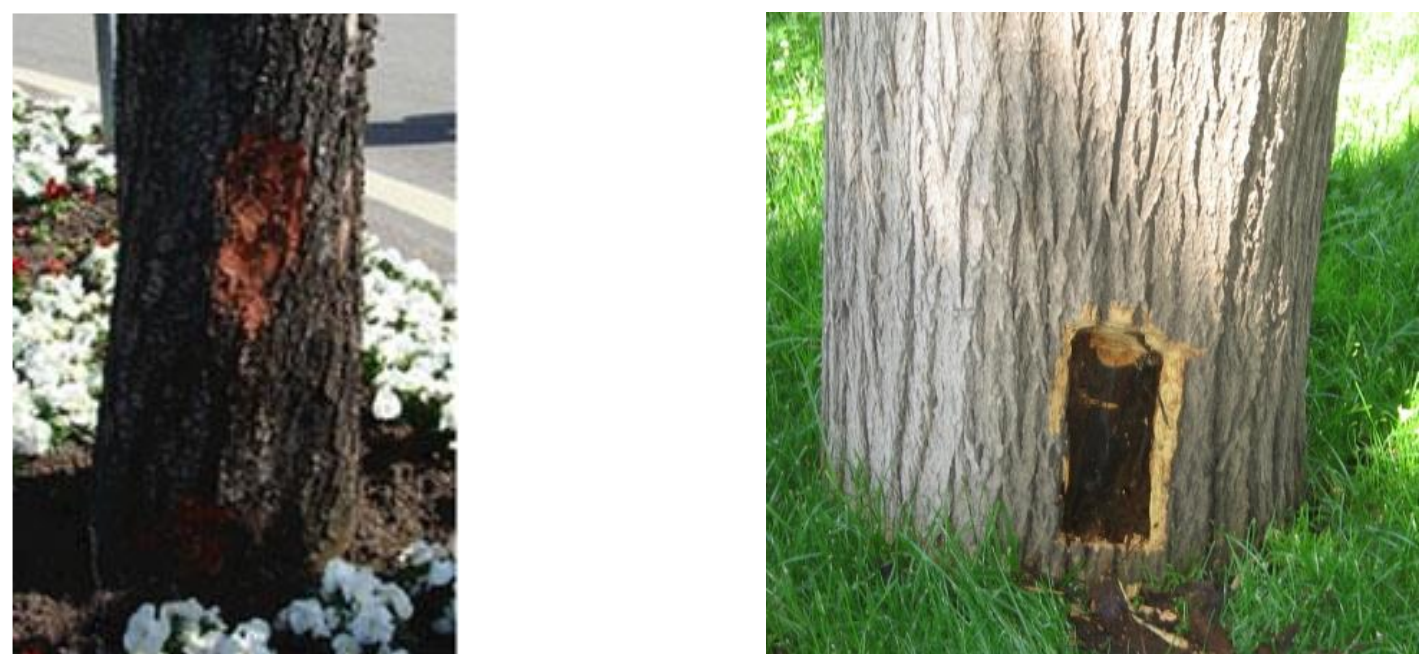

Şekil 9 Kurumakta olan atkestaneleri gövdelerinde kök boğazında görülen kahverengi nekrozlar Figure 9 Brown necrosis observed on horse chestnuts showing decline symptoms

\section{Karaçam}

Ülkemizde karaçamlarda ölüm çok dikkat çeken bir durum değildir. Ancak Kastamonu, Taşköprü, Karapürçek orman ağaçlama sahasında şiddetli kurumalar (Şekil 8a) görülmüş ve bu bölgede yapılan incelemelerde bitkilerde şiddetli bir kök çürüklüğü saptanmıştır (Yayımlanmamış çalışma) (Şekil 8).

Kurumakta olan ağaçların kök rizosferinden alınan toprak örneklerinden tuzaklama yöntemi ile Phytophthora cambivora ve $P$. cryptogea elde edilmiştir.

\section{Şimşir}

Şimşirlerde son yıllarda yürütülen çalışmalarda ülkemizin bazı bölgelerinde tamamen kurumuş şimşirlerin rizosfer topraklarında 2 Phytophthora türü elde edilmiştir. Bunlarda $P$. plurivora Karadeniz Bölgesinde 2 ayr1 yerden, $P$. occultans bir bölgeden elde edilmiştir. $\mathrm{Bu}$ türlerin ikisi de şimşirlerde patojen bulunmuştur. Şimdilik sınırlı alanlarda bulunan bu türlerin ilerde yayılma olasılıkları vardır (Akıllı ve ark., 2017).

\section{Park ve Süs Bitkilerinde Görülen Türler}

\section{Atkestanesi}

Park ağaçları arasında Phytophthora kök çürüklüğüne en hassas türler arasında Atkestanesi yer almaktadır. Gerek ülkemizde gerekse diğer ülkelerde bu park ağacında sekiz Phytophthora türünün hastalık yaptığı kayıtlıdır (Werres ve ark., 2012).

Ülkemizde Atkestanesinde Phytophthora ile ilgili kayıt 2002 yılına dayanmaktadır. Intini ve ark., (2002) Ankara'da bir parkta Atkestanesinde yaprak sararması, yapraklarda küçülme, gövde ve ana dallarda koyu renkli akıntılı nekrozlara rastladıklarını ve bu nekrozların çevresindeki dokulardan $P$. cactorum izole ettiklerini ve sağlıklı dallara inoküle edilen Atkestanelerinde aynı belirtileri elde ettiklerini bildirmişlerdir.

Akıllı ve ark., (2012c) daha sonra Türkiye Büyük Millet Meclisi girişinde yer alan yaklaşık 40 yıllık atkestanelerinde birkaç ağaçta kurumaları incelemişler ve bu ağaçların kök boğazlarında kahverengi nekrozların oluştuğunu gözlemlemişlerdir (Şekil 9). Araştırıcılar kök çevresinde aldıkları toprak ve ince kök örneklerinden atkestanesi için Türkiye'de yeni bir Phytophthora türü, $P$. citrophthora elde etmişlerdir. Araştırıcılar bu türü gerek morfolojik özelliklerine gerekse moleküler özelliklerine göre (ITS gen bölgesi dizini belirlenerek) teşhis etmişlerdir. Akıllı ve ark., (2012c) at kestanelerindeki bu türün ağaçların kök çevresine çiçek ekilmesi ile bulaşabileceği ve çok sulama ile hastalığın şiddetleneceğini vurgulamışlardır. Araştırıcılar daha sonra Ankara parklarında yaptıkları incelemelerde Gençlik Parkında atkestanelerinde aynı tipte kurumaların olduğunu ve yine bu tip ağaçların kök çevresinde alınan toprak örneklerinde $P$. citrophthora izole ettiklerini belirtmişlerdir.

Atkestanesi Phytophthora enfeksiyonlarına çok duyarlı bir ağaç olup dünyada bu ağaca saldıran 8 Phytophthora türü belirlenmiştir. Bunlar; P. cactorum, P. cambivora, P. citricola P. citrophthora, $P$. kernoviae, $P$. megasperma, $P$. obscural, $P$. ramorum' dir (Werres ve ark., 2012).

\section{Kokară̆aç}

Kokarağaç çok fazla kullanılan bir park ağacı olmamakla beraber hızlı gelişmesi nedeniyle bazen tercih edilmektedir. Ankara parklarında yaptığımız incelemelerde Kurtuluş parkında yer alan kokarağaçlarda kök çürüklüğü nedeniyle şiddetli kurumalar gözlenmiş ve alınan toprak örneklerinden Phytophthora nicotianae izole edilmiştir (Şekil 10). Bu ağaçta şu ana kadar herhangi bir Phytophthora türü saptanmamıştır.

\section{Fidanlıklarda Belirlenen Türler}

Ülkemiz orman ve park ağacı üreten fidanlıklar farklı farklı zamanlarda hastalıklar yönünden incelenmiş ve Phytophthora hastalıklarının birçok fidanlıkta değişik ağaç türlerinde bulunduğu belirlenmiştir. Orman fidanlıklarında saptanan Phytophthora türleri Tablo 4' de sunulmuştur. 
Tablo 4 Orman fidanlıklarında saptanan Phytophthora türleri Table 4 Phytophthora species determined in forest nurseries

\begin{tabular}{|c|c|c|c|}
\hline Phytophthora türleri & Bulunduğu fidanlık & Bulunduğu bitki & Kaynaklar \\
\hline $\begin{array}{l}\text { P. cinnamomi } \\
\text { P. cryptogea }\end{array}$ & $\begin{array}{l}\text { Ordu, Devrek (Gökçebey), Akçakoca } \\
\text { Çankırı (Kenbağ) }\end{array}$ & $\begin{array}{l}\text { Kestane } \\
\text { Karaçam }\end{array}$ & $\begin{array}{l}\text { Ak1lli ve ark. (2010) } \\
\text { Ak1ll ve ark. (2010) }\end{array}$ \\
\hline P. cactorum & İzmir (Torbalı) & Defne & \multirow{4}{*}{ Aday (2014) } \\
\hline P. citricola & $\begin{array}{l}\text { Adapazarı (Hendek) } \\
\text { Muğla (Gökova) } \\
\text { Antalya (Elmalı) }\end{array}$ & $\begin{array}{l}\text { Şimşir } \\
\text { Şimşir } \\
\text { Sedir }\end{array}$ & \\
\hline P. megasperma & Adapazarı (Hendek) & Kestane & \\
\hline P. syringae & $\begin{array}{l}\text { İzmir (Torbalı) } \\
\text { Antalya (Elmalı) }\end{array}$ & $\begin{array}{l}\text { Sedir } \\
\text { Sedir }\end{array}$ & \\
\hline
\end{tabular}

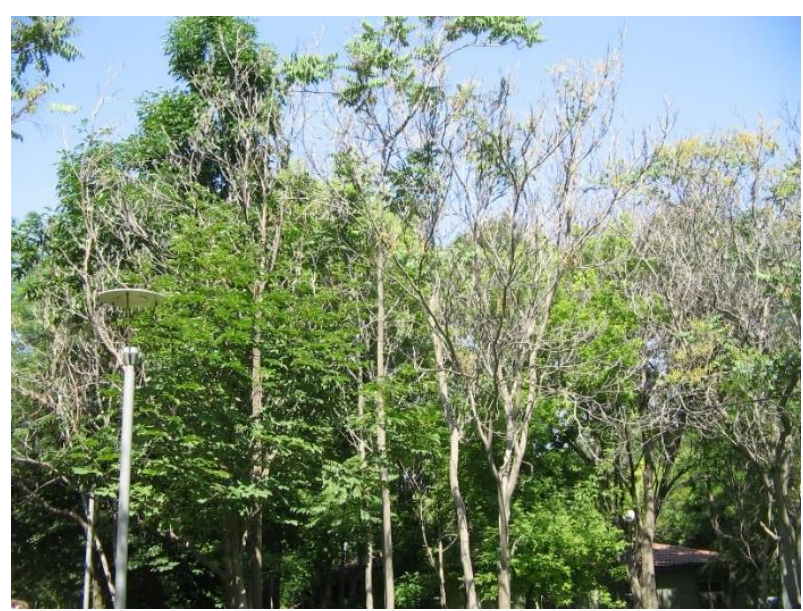

Şekil 10 Kokarağaçlarda Phytophthora nicotianae’ dan dolayı kurumalardan görünüm

Figure 10 A view from the trees of heaven caused by Phytophthora nicotianae

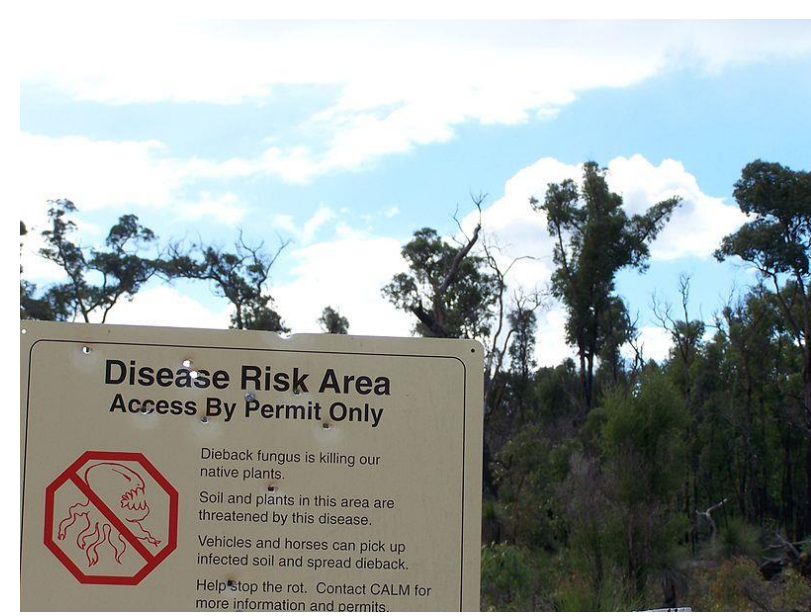

Şekil 11 Phytophthora' ların yayılmasına karşı alınan uyarı önleminden görünüm

Figure 11 A notice put to prevent distribution of Phytophthora spp.

\section{Phytophthora Hastalıklarına Karşı Alınması Gereken Önlemler}

- Phytophthora hastalıkları birçok konukçuyu hastalandıran ve çok hızlı gelişen etmenlerdir. Bu etmenlerin yol açtığı kök ve kök boğazı hastalıklarının önlenmesinde kullanılan etkili ve çevreye olumsuz etkisi olmayan ilaçlar mevcuttur. Bunlardan en etkili ve kullanışılı olan Fosforoz asit bileşimli ilaçlardır. Bu etken madde yapraklardan uygulandığ gibi gövde enjeksiyonu tekniği ile de başarılı bir şekilde kullanılabilmektedir. Ancak bu uygulamaların sürekli yapılması gerekir bu da işgücü ve mali bir yük getirmektedir. Ayrıca hızlı yayılan ve çok konukçulu olan $P$. ramorum ve $P$. kernoviae gibi türlerle savaşta bu uygulamalar da pratik değildir.

- Phytophthora hastalıkların önlenmesinde öncelikle hastalıkların bir yere bulaşmalarının önüne geçilmelidir. Hastalıkların taşınmasında en önemli rolü hastalıklı fidanlar oynamaktadır. Bu hastalıkların karantina önlemleri ile taşınmasının önlenmesi de çok zordur. Çünkü bulaşık çok sayıda materyalin hem test edilmesi pratik değildir hem de çoğu kez bu hastalıklar belirtisiz taşınmaktadır. Fidanlarla hastalıkların taşınmasının önlenmesi için alınması gereken önlemlerin ortaya konması için açılan COST aksiyonu (FP1401) çalışmalarında fidanlıkların uzman kişilerce sıkı kontrolü istenmektedir.
- Hastalıkların bulunduğu yerlerde bunların yayılmamaları için önlemler alınmalıdır (Şekil 11). Bunun için bu hastalıkların yayılış alanları belirlenmeli, mümkünse bu alanlar aşağıda şekilde görüldüğü gibi, araç ve hayvan girişlerine kapatılmalıdır.

- Tehlikeli türler, $P$. ramorum, gibi ilk görüldükleri zaman hızlı bir şekilde eradike edilmeli (Şekil 12) ve bu türün olduğu ülkelerden fidan ithali durdurulmalıdır. $\mathrm{Bu}$ gibi hastalıklar için dünyada fidan ticaretinin durdurulması önerileri de mevcuttur. Örneğin Montesclaros deklersyonu gibi (https://www.iufro.org/science/divisions/division7/70000/publications/montesclaros-declaration/).

- Ağaç diplerine çiçek dikimi de bu hastalıkların bulaşmasında önemli bir kaynaktır. Bu nedenle süs bitkileri fide üretim yerleri de bu hastalıklar yönünden kontrol edilmeli, ağaç diplerine çiçek dikiminden vazgeçilmelidir (Akıllı ve ark., 2012c).

- Bir ülkede bu hastalıkların yayıldıkları sınırlar belirlenmeli, hastalıkların yayılışlarını önlemek için halk ve ilgili kuruluşlar bilinçlendirilmeli, bu iletişim araçları ile kolaylaştırılmalıdır. 


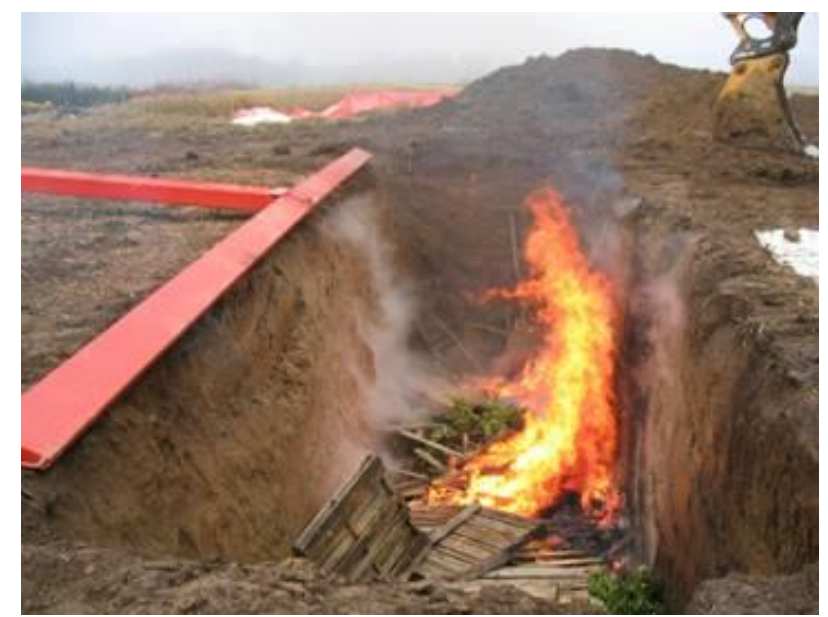

Şekil 12 Phytophthora ile enfeksiyonlu fidanların yakılarak yok edilmesinden görünüm

Figure 12 A Picture showing destruction of infected saplings by burning

\section{Kaynaklar}

Aday Kaya G. 2014. Türkiye'nin Batısında Yer Alan Orman Fidanlıklarında Geniş Ve İğne Yapraklı Fidan Türlerinde Kök Çürüklüğüne Neden Olan Ökaryot Patojenlerin Belirlenmesi. Süleyman Demirel Üniversitesi, Fen Bilimleri Enstitüsü, Doktora tezi, 140s. Isparta.

Akdoğan S. 1970. Kestane Mürekkep Hastalığı (Phytophthora cambivora Petri) mücadelesi üzerine araştırmalar. Bitki Koruma Bülteni, 10(2): 121-130.

Akıllı S, Katırcıoğlu YZ, Maden S. 2010. Türkiye'deki Bazı Orman Fidanlıklarında Fungusların Neden Olduğu Hastalıklar Üzerinde Çalışmalar. Düzce Üniversitesi, Ormanc1lik Dergisi, 6(2):1-10.

Akıllı S, Ulubaş-Serçe Ç, Katırcıoğlu YZ. Maden S. 2012a. Involvement of Phytophthora spp. In chestnut decline in the Black Sea region of Turkey. Forest Pathology, 42(5):377386.

Akıllı S, Katırcıŏlu YZ, Maden S. 2012b. Phytophthora Türlerinin Marmara Bölgesi Orman Ekosisteminin Önemli Odunsu Taksonlarından, Kestane (Castanea sativa) Kurumalarındaki Rollerinin Belirlenmesi. 1110494 nolu TÜBİTAK projesi sonuç raporu, 25s. Ankara.

Akıllı S, Ulubaş-Serçe Ç, Katırcıoğlu YZ, Maden S. 2012c. Phytophthora citrophthora, a new pathogen causing decline on horse chestnut in Turkey. Forest Pathology, 42(4), pages 299-304.

Akıllı S, Ulubaş Serçe Ç, Katırcıŏlu YZ, Maden S. 2013a. Phytophthora dieback on Narrow leaved ash in the Black Sea region of Turkey. Forest Pathology, 43(3): 252-256.

Akıllı S, Ulubaş Serçe Ç, Katırcıoğlu YZ, Maden S. 2013b. Does Pythium anandrum contribute to the dieback of sessile oak (Quercus petraea) in Turkey? Forest Pathology, 43(6): 505-508.

Akıllı S, Katırcıoğlu YZ, Maden S. 2017. Marmara ve Karadeniz Bölgeleri Şimşir Orman Alanlarında ve Fidanlıklarında Görülen Fungal Kuruma Nedenlerinin Araştırılması. TÜBİTAK-1001 proje sonuç raporu:41s.

Anonim 2006. Orman ve Su İşleri Bakanlığ Müdürlüğü, Meşe Ormanlarının Rehabilitasyonu Eylem Plan1, 2006-2015.

Anonim 2014. Orman ve Su İşleri Bakanlığı, Orman Genel Müdürlüğü, 2013-2017 Kestane Eylem Plan1.

Anonymous 2018. NCBI Phytophthora web sayfas1. https://www.ncbi.nlm.nih.gov/mesh?Db=mesh\&Cmd=Detai lsSearch\&Term $=\% 22$ Phytophthora $\% 22 \% 5 \mathrm{BmeSH}+\mathrm{Terms} \%$ $5 \mathrm{D}$
Aykut Y, Uslu E, TekinBabaç M. 2008. Karyological studies on four Quercus L. Species in Turkey. Caryologia, 61(4): 397401.

Balci Y, Halmschlager E. 2003. Phytophthora species in oak ecosystems in Turkey and their association with declining oak trees. Plant Pathology, 52: 694-702.

Biçiçi M, Çınar A, 1990. A review of Phytophthora diseases of different Mediterranean crops in Turkey. EPP/EPPO Bulletin, 20:101-105.

Brasier CM, Jung T. 2003. Progress in understanding Phytophthora diseases of trees in Europe. In: Phytophthora in forests and natural ecosystems. Proceedings of the Second International Meeting of IUFRO Working Party 7.02.09, Albany, Western Australia,2001, eds JA McComb, GEStJ Hardy and I Tommerup. Murdoch University Print, Perth, Australia, 4-18.

Brasier CM, Jung T. 2006. Recent developments in Phytophthora diseases of trees and natural ecosystems in Europe. Progress in Research on Phytophthora Diseases of Forest Trees Proceedings of the Third International IUFRO Working Party S07.02.09 Meeting at Freising, Germany, 11-18 September 2004.

Brasier CM. 1996. Phytophthora cinnamomi and oak decline in southern Europe. Environmental constraints including climate change. Ann.Sci.For., 53:347-358.

Corcobado Sánchez T. 2012. Quercus ilex L. (Holm meşesi)‘ de Phytophthora. JKI Data Sheets - Plant Diseases and Diagnosis, ISSN: 2191-1398 :1-9 DOI: 10.5073/ jkidspdd.2013.011.

Çanakçıŏlu H, Eliçin G. 1998. Fitopatoloji (özel bölüm). İstanbul Üniversitesi Orman Fakültesi Yayınları: 28-31, İstanbul.

Çeliker M, Onoğur E. 2009. Preliminary Studies on the Fungal Disorders Especially on Ink Disease Causing Decline of chestnut Trees in Turkey. Proceedings of International Workshop on Chestnut Management in Mediterranean Countries Eds.: A. Soylu and C. Mert. Acta Hort. 815: 227-231.

Denman S, Kirk SA, Moralejo E, Webber J. 2009. Phytophthora ramorum and Phytophthora kernoviae on naturally infected asymptomatic foliage in Bulletin OEPP/EPPO Bulletin 39(1):105 - 111 March 2009. DOI: 10.1111/j.13652338.2009.02243.x

Erdem R. 1951. Türkiye'deki Kestane Ölümünün Sebepleri ve Savaş, İmkanları. Tarım Bakanlığı, Orman Genel Müdürlüğü, Say1 No: 102, Seri 11, Ankara

Erwin DC, Ribeiro OK. 1996. Phytophthora Diseases Worldwide. St Paul, MN: APS Press.

Frankel SJ.2008. Sudden oak death and Phytophthora ramorum in the USA:a management challenge Australasian Plant Pathology, 37: 19-25.

Grünwald NJ, Goss EM, Press CM. 2008. Phytophthora ramorum: a pathogen with a remarkably wide host range causing sudden oak death on oaks and ramorum blight on woody ornamentals. Molecular Plant Pathology, 9(6): 729740.

Hansen E, Reeser P, Sutton W, Sims L. 2013. Host and Habitat Index for Phytophthora Species in Oregon. Proceedings of the Sudden Oak Death Fifth Science Symposium, General Technical Report PSW-GTR-243:142-145.

Hansen EM. 2015. Phytophthora Species Emerging as Pathogens of Forest Trees. Current Forestry Reports, 1(1): $16-24$.

Hook KK. 2011. Susceptibility of native plant species to Phytophthora cinnamomi and the spread of Phytophthora dieback in South Australia. Doctora thesis. The University of Adelaide. School of Agriculture, Food and Wine Faculty of Sciences: 1-200.

Intini M, Gurer M, Ozturk S. 2002. First Report of Bleeding Canker Caused by Phytophthora cactorum on Horse Chestnut in Turkey. Plant Diseases, 86 (6): 697. 
Jung T, Orlikowski L, Henricot B, Abad-Campos P, Aday AG, Aguín Casal O, Bakonyi J, Cacciola SO, Cech $T$, Chavarriaga D, Corcobado T, Cravador A, Decourcelle T, enton G, Diamandis S, Doğmuş-Lehtijärvi HT, Franceschini A, Ginetti B, Green S, Glavendekić M, Hantula J, Hartmann G, Herrero M, Ivic D, Horta Jung M, Lilja A,Keca N, Kramarets V, Lyubenova A, Machado H, Magnano di San Lio G, Mansilla Vázquez PJ, Marçais B, Matsiakh I, Milenkovic I, Moricca S, Nagy Z Á, Nechwatal J, Olsson C, Oszako T, Pane A, Paplomatas EJ, Pintos Varela C, Prospero S, Rial Martínez C, Rigling D, Robin C, Rytkönen A, Sánchez M E, Sanz Ros A V, Scanu B, Schlenzig A, Schumacher J, Slavov S, Solla A, Sousa E, Stenlid J, Talgø V, Tomic Z, Tsopelas P, Vannini A, Vettraino AM, Wenneker M, Woodward S, Peréz-Sierra A. 2016.Widespread Phytophthora infestations in European nurseries put forest, semi-natural and horticultural ecosystems at high risk of Phytophthora diseases, For. Path. 46:134-163.

Jung T, Blaschke H. 1995. Phytophthora root rot in declining forest trees. - Phyton (Horn, Austria), 36 (3): 95 - 102.

Katırcıoğlu YZ, Akıllı S, Maden S. 2017. Ege Bölgesi kestane (Castanea sativa) alanlarında kurumalara neden olan Phytophthora türleri ve yaygınlıklarının belirlenmesi. Ankara Üniversitesi, 15B0447002 nolu Bilimsel Araştırma Projesi sonuç raporu: 22s.
Lilja A, Kokkola M, Hantula J, Parikka P. 2006. Phytophthora spp. a new threat to tree seedlings and trees. Aktuelt fra skogforskningen: 48-53.

Maden S, Akıllı S, Katırcioğlu YZ. 2012. Phytophthora türlerinin Karadeniz Bölgesi orman ekosisteminin önemli odunsu taksonlarından Meşe (Quercus spp.), Kestane (Castanea sativa) ve Orman gülü (Rhododendron spp.) kurumalarındaki rollerinin belirlenmesi. TÜBİTAK $108 \mathrm{O} 888$ nolu proje sonuç raporu.

Neves D, Maia C. 2012. Quercus suber L. (mantar meşesi)‘ de Phytophthora. JKI Data Sheets, Plant Diseases and Diagnosis, ISSN: 2191-1398:1-9.

Tjosvold SA, Buermeyer KR, Blomq1st C, Frankel S. 2005. Nursery guide for diseases caused by Phytophthora ramorum on ornamentals: Diagnosis and Management. University of Californa, ANR Publication 8156.

Vettraino AM, Morel O, Perlerou C, Robin C, Diamandis S, Vannini A. 2005. Occurrence and distribution of Phytophthora species in European chestnut stands, and their association with ink disease and crown decline. European Journal Plant Pathology, 111:169-180.

Werres S, Ak1ll1 S, Maden S. 2012. Aesculus hippocastanum L. (At kestanesi)' da Phytophthora. JKI Data Sheets, ISSN: 2191-1398: 1-8. 